\title{
Mild Dehydrogenation of Ammonia Borane Complexed with Aluminum Borohydride
}

\author{
Iurii Dovgaliuk, Cécile S. Le Duff, Koen Robeyns, Michel Devillers, and Yaroslav Filinchuk* \\ Institute of Condensed Matter and Nanosciences, Université catholique de Louvain, 1348 Louvain-la-Neuve, Belgium
}

Supporting Information

ABSTRACT: Ammonia borane is a promising hydrogen store. However, its dehydrogenation is stepwise, nonreversible, and accompanied by formation of undesirable byproducts. We report on a new $\mathrm{Al}\left(\mathrm{BH}_{4}\right)_{3} \cdot \mathrm{NH}_{3} \mathrm{BH}_{3}$ complex containing 17.7 wt \% hydrogen, which undergoes a two-step thermal decomposition below $100{ }^{\circ} \mathrm{C}$. The combination of volumetric, gravimetric, crystallographic, and nuclear magnetic resonance studies shows that both in the solid state and in toluene solutions, the $\mathrm{Al}$-coordinated $\mathrm{NH}_{3} \mathrm{BH}_{3}$ already releases two $\mathrm{H}_{2}$ molecules per $\mathrm{Al}$ at $70{ }^{\circ} \mathrm{C}$. Contrary to that of the pristine ammonia borane, this process is endothermic, suggesting a possibility for direct rehydrogenation. The dehydrogenation of $\mathrm{Al}\left(\mathrm{BH}_{4}\right)_{3} \cdot \mathrm{NH}_{3} \mathrm{BH}_{3}$ contrasts with the complete destruction of alkali and alkaline earth metal borohydride complexes with ammonia borane in the first decomposition step. Other Al-based Lewis acids, less challenging with respect to the stability and safety than $\mathrm{Al}\left(\mathrm{BH}_{4}\right)_{3}$, may be good agents for supporting the reversible dehydrogenation of $\mathrm{NH}_{3} \mathrm{BH}_{3}$ under mild conditions.

\section{INTRODUCTION}

In recent years, metal borohydrides $\mathrm{M}\left(\mathrm{BH}_{4}\right)_{n}{ }^{1,2}$ and $\mathrm{M}-\mathrm{B}-\mathrm{N}-$ $\mathrm{H}$ systems ${ }^{3,4}$ of metal amidoboranes (MABs), amine metal borohydrides (AMBs), and complexes with ammonia borane $\mathrm{NH}_{3} \mathrm{BH}_{3}(\mathrm{AB})$ have been among the most attractive materials for potential solid-state hydrogen storage as they exceed by far the year 2017 system targets of 5.5 wt \% hydrogen and $40 \mathrm{~g} / \mathrm{L}$ gravimetric density set by the U.S. Department of Energy. ${ }^{5}$ Several metal borohydrides $\mathrm{M}\left(\mathrm{BH}_{4}\right)_{n}\left(n=1, \mathrm{M}=\mathrm{Li}^{+}\right.$or $\mathrm{Na}^{+} ;{ }^{6,7}$ $n=2, \mathrm{M}=\mathrm{Be}^{2+}, \mathrm{Mg}^{2+}$, or $\mathrm{Ca}^{2+} ;{ }^{8-10} n=3, \mathrm{M}=\mathrm{Al}^{3+}$ or $\mathrm{Ti}^{3+11,12}$ ) have been studied as potential hydrogen storage media. However, the hydrogen desorption temperatures for alkali and most alkaline earth metal borohydrides are far from the range of $60-120^{\circ} \mathrm{C}$ useful for hydrogen fuel cells: ${ }^{13}$ indeed, desorption temperatures of $\sim 470{ }^{\circ} \mathrm{C}$ for $\mathrm{LiBH}_{4}$ and $290-500$ ${ }^{\circ} \mathrm{C}$ for $\mathrm{Mg}\left(\mathrm{BH}_{4}\right)_{2}$ and $\mathrm{Al}\left(\mathrm{BH}_{4}\right)_{3}$ with $\mathrm{Be}\left(\mathrm{BH}_{4}\right)_{2}$ make them unpractical. The high stability of borohydrides can be decreased using formation of bimetallic borohydrides. Their stability decreases with increasing Pauling electronegativity $\left(\chi_{p}\right)$ of the complex-forming cation. ${ }^{14,15}$ The most unstable metal borohydride complexes contain highly electronegative $\mathrm{Al}^{3+}, \mathrm{Zn}^{2+}$, and $\mathrm{Cd}^{2+}\left(\chi_{\mathrm{p}}\right.$ values of $1.61,1.65$, and 1.69 , respectively), which create weaker $\mathrm{B}-\mathrm{H}$ bonds, together with alkali metal cations $\left(0.79 \leq \chi_{\mathrm{p}} \leq 0.98\right)$. In particular, the series of bimetallic borohydrides of $\mathrm{Al}_{3} \mathrm{Li}_{4}\left(\mathrm{BH}_{4}\right)_{13}, \mathrm{NaAl}\left(\mathrm{BH}_{4}\right)_{x} \mathrm{Cl}_{4-x}$, KAl$\left(\mathrm{BH}_{4}\right)_{4}{ }^{16-18} \mathrm{LiZn}_{2}\left(\mathrm{BH}_{4}\right)_{5}, \mathrm{NaZn}_{2}\left(\mathrm{BH}_{4}\right)_{5}, \mathrm{NaZn}\left(\mathrm{BH}_{4}\right)_{3}$, and $\mathrm{KZn}\left(\mathrm{BH}_{4}\right)_{3}{ }^{19,20}$ as well as $\mathrm{KCd}\left(\mathrm{BH}_{4}\right)_{3}$ and $\mathrm{K}_{2} \mathrm{Cd}\left(\mathrm{BH}_{4}\right)_{4}{ }^{21}$ decompose at rather low temperatures. However, they evolve toxic diborane $\mathrm{B}_{2} \mathrm{H}_{6}$ during decomposition, which contaminates the fuel cells and decreases the reversibility of these potential materials.

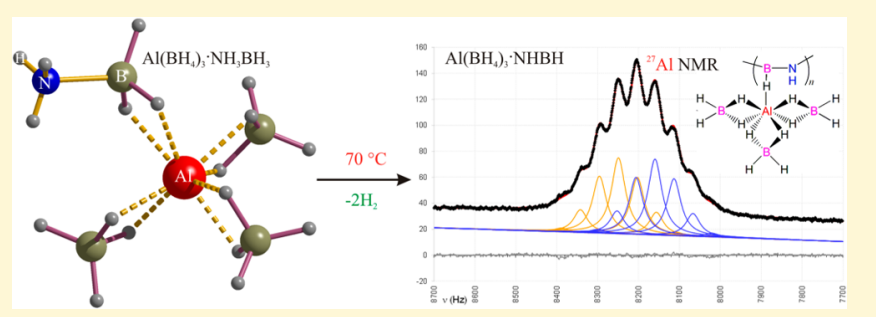

Another group of materials with competitive hydrogen storage properties consists of metal borohydride complexes with ammonia and ammonia borane, $\mathrm{NH}_{3} \mathrm{BH}_{3}$. The presence of $\mathrm{N}-\mathrm{H}^{\sigma+} \ldots \mathrm{H}^{\sigma-}-\mathrm{B}$ dihydrogen bonds in these compounds considerably decreases the dehydrogenation temperatures, to the range of $60-250{ }^{\circ} \mathrm{C}$. Several amine metal borohydrides (AMBs) are considered promising hydrogen storage materials: $\mathrm{LiBH}_{4} \cdot \mathrm{NH}_{3}{ }^{22,23} \mathrm{M}\left(\mathrm{BH}_{4}\right)_{2} \cdot 2 \mathrm{NH}_{3}\left(\mathrm{M}=\mathrm{Mg}^{2+}, \mathrm{Ca}^{2+}\right.$, or $\left.\mathrm{Zn}^{2+}\right),{ }^{24-26} \mathrm{Ti}\left(\mathrm{BH}_{4}\right)_{3} \cdot 3 \mathrm{NH}_{3}{ }^{27} \mathrm{Al}\left(\mathrm{BH}_{4}\right)_{3} \cdot n \mathrm{NH}_{3},{ }^{28,29} \mathrm{LiMg}-$ $\left(\mathrm{BH}_{4}\right)_{3} \cdot 2 \mathrm{NH}_{3},{ }^{30,31} \mathrm{Li}_{2} \mathrm{Ti}\left(\mathrm{BH}_{4}\right)_{5} \cdot 5 \mathrm{NH}_{3}$, and $\mathrm{Li}_{2} \mathrm{Al}\left(\mathrm{BH}_{4}\right)_{5}$. $6 \mathrm{NH}_{3}{ }^{27,32}$ The hydrogen decomposition properties of AMBs are affected both by the nature of the metal cation and by the number of coordinated ammonia molecules per cation. It was reported that $\mathrm{LiBH}_{4} \cdot \mathrm{NH}_{3}$ and $\mathrm{Ca}\left(\mathrm{BH}_{4}\right)_{2} \cdot 2 \mathrm{NH}_{3}$ mainly release ammonia rather than hydrogen under dynamic flow; ${ }^{33,24}$ however, cobalt-catalyzed thermolysis of $\mathrm{LiBH}_{4} \cdot \mathrm{NH}_{3}$ releases 17.8 wt $\% \mathrm{H}_{2} \cdot{ }^{34}$ The other representatives, $\mathrm{Mg}\left(\mathrm{BH}_{4}\right)_{2} \cdot 2 \mathrm{NH}_{3}$ and $\mathrm{Al}\left(\mathrm{BH}_{4}\right)_{3} \cdot 6 \mathrm{NH}_{3}$, produce only traces of ammonia, ${ }^{24,28}$ while $\mathrm{Zn}\left(\mathrm{BH}_{4}\right)_{2} \cdot 2 \mathrm{NH}_{3}, \mathrm{Ti}\left(\mathrm{BH}_{4}\right)_{3} \cdot 3 \mathrm{NH}_{3}$, and $\mathrm{Al}\left(\mathrm{BH}_{4}\right)_{3} \cdot 4 \mathrm{NH}_{3}-$ $\mathrm{LiBH}_{4}$ composite, bimetallic $\mathrm{LiMg}\left(\mathrm{BH}_{4}\right)_{3} \cdot 2 \mathrm{NH}_{3}, \mathrm{Li}_{2} \mathrm{Ti}\left(\mathrm{BH}_{4}\right)_{5}$. $5 \mathrm{NH}_{3}$, and $\mathrm{Li}_{2} \mathrm{Al}\left(\mathrm{BH}_{4}\right)_{5} \cdot 6 \mathrm{NH}_{3}$ release high-purity hydrogen. $^{24,27,28}$ The detailed electronic structure of $\mathrm{M}\left(\mathrm{BH}_{4}\right)_{2}$. $2 \mathrm{NH}_{3}\left(\mathrm{M}=\mathrm{Mg}^{2+}, \mathrm{Ca}^{2+}\right.$, or $\left.\mathrm{Zn}^{2+}\right)$ reveals a highly ionic character of $\mathrm{Ca}^{2+}$ in $\mathrm{Ca}\left(\mathrm{BH}_{4}\right)_{2} \cdot 2 \mathrm{NH}_{3}$ and partial covalence of $\mathrm{Mg}-\mathrm{NH}_{3}$ and $\mathrm{Zn}-\mathrm{NH}_{3}$, which prevents the release of $\mathrm{NH}_{3}$ from the latter complexes. ${ }^{35}$

Received: September 30, 2014

Revised: December 13, 2014

Published: January 15, 2015 
Despite the high hydrogen content of ammonia borane $(\sim 19.6 \%)$ and acceptable stability upon transportation and storage, $\mathrm{NH}_{3} \mathrm{BH}_{3}$ undergoes stepwise decomposition with $6.5 \%$ hydrogen released below $112{ }^{\circ} \mathrm{C}$ and $14.5 \%$ near $200{ }^{\circ} \mathrm{C}$, all accompanied by undesirable borazine and aminoborane $\mathrm{NH}_{2} \mathrm{BH}_{2} \cdot{ }^{36,37}$ A considerable improvement is achieved by forming metal salts of ammonia borane. This improves the decomposition temperature to $\sim 90{ }^{\circ} \mathrm{C}$ for $\mathrm{Li}$ - or $\mathrm{NaNH}_{2} \mathrm{BH}_{3}$, giving way to a large family of materials. Ammonia borane metal-containing derivatives (MABs) $\mathrm{M}\left(\mathrm{NH}_{2} \mathrm{BH}_{3}\right)_{n}(n=1, \mathrm{M}$ $=\mathrm{Li}^{+}$or $\mathrm{Na}^{+} ; n=2, \mathrm{M}=\mathrm{Ca}^{2+}$ or $\left.\mathrm{Mg}^{2+}\right),{ }^{38-41}$ including bimetallic $\mathrm{NaLi}\left(\mathrm{NH}_{2} \mathrm{BH}_{3}\right)_{2}$ and $\mathrm{Na}_{2} \mathrm{Mg}\left(\mathrm{NH}_{2} \mathrm{BH}_{3}\right)_{4}$ and mixedanion $\mathrm{Li}_{2}\left(\mathrm{NH}_{2} \mathrm{BH}_{3}\right)\left(\mathrm{BH}_{4}\right) / \mathrm{LiNH}_{2} \mathrm{BH}_{3}$, were obtained in recent years. ${ }^{42-44}$ All the listed MABs release hydrogen as well as toxic ammonia and traces of $\mathrm{NH}_{2} \mathrm{BH}_{2}$. For the mixed $\mathrm{MAB}-\mathrm{AB}$ complex $\mathrm{LiNH}_{2} \mathrm{BH}_{3} \cdot \mathrm{NH}_{3} \mathrm{BH}_{3}$, the hydrogen release was reported to be occur to $14.0 \mathrm{wt} \%$ in a stepwise manner at 80 and $140{ }^{\circ} \mathrm{C}$, and neither borazine nor aminoborane was detected. ${ }^{45}$ Metal borohydride-ammonia borane complexes $\mathrm{M}\left(\mathrm{BH}_{4}\right)_{n}\left(\mathrm{NH}_{3} \mathrm{BH}_{3}\right)_{m}\left(n=1, m=1\right.$ or 2 for $\mathrm{M}=\mathrm{Li}^{+} ; n=m=2$ for $\mathrm{M}=\mathrm{Ca}^{2+}$ or $\mathrm{Mg}^{2+}$ ) showed more facile hydrogen desorption with less ammonia evolution compared to the case for pure ammonia borane and MABs. ${ }^{46-49}$ Further improvements in the properties of these complexes were achieved by combining some $\mathrm{AMBs}$ with ammonia borane, such as $\mathrm{Li}_{2} \mathrm{Al}\left(\mathrm{BH}_{4}\right)_{5}\left(\mathrm{NH}_{3} \mathrm{BH}_{3}\right)_{3} \cdot 6 \mathrm{NH}_{3}$ and $\mathrm{Mg}\left(\mathrm{BH}_{4}\right)_{2} \cdot 2 \mathrm{NH}_{3}$ $\mathrm{NH}_{3} \mathrm{BH}_{3}$, where high-purity hydrogen was released. ${ }^{50,48}$

Compounds in $\mathrm{Al}-\mathrm{B}-\mathrm{N}-\mathrm{H}$ systems are among the best in terms of hydrogen storage properties. However, the number of components involved goes increasingly high, leaving little (if any) chance for their reversibility. Here we report a new $\mathrm{Al}\left(\mathrm{BH}_{4}\right)_{3} \cdot \mathrm{NH}_{3} \mathrm{BH}_{3}$ complex with 17.7 wt \% hydrogen, combining only two hydrogen rich molecules: $\mathrm{Al}\left(\mathrm{BH}_{4}\right)_{3}$ and $\mathrm{NH}_{3} \mathrm{BH}_{3}$. Remarkably, the complexation transforms aluminum borohydride into a stable solid, which undergoes a two-step thermal decomposition at temperatures below $100{ }^{\circ} \mathrm{C}$. We report on the synthesis, crystal structures, and Raman spectroscopic studies of the complex, as well as thermal analysis, ${ }^{11} \mathrm{~B}$ and ${ }^{27} \mathrm{Al}$ nuclear magnetic resonance (NMR) spectroscopy, and volumetric studies of its decomposition and reversibility.

\section{EXPERIMENTAL SECTION}

Synthesis. Caution! $\mathrm{Al}\left(\mathrm{BH}_{4}\right)_{3}$ is a highly pyrophoric liquid that explodes on contact with air. All manipulations were conducted in a nitrogen-filled drybox. The reactions were performed using commercially available reagents: $\mathrm{AlCl}_{3}$ and $\mathrm{NH}_{3} \mathrm{BH}_{3}$ (both from Sigma-Aldrich at $\geq 95 \%$ purity) and $\mathrm{LiBH}_{4}$ ( $\geq 96 \%$ purity, Boss chemical industry Co.). The $\mathrm{Al}\left(\mathrm{BH}_{4}\right)_{3} \cdot \mathrm{NH}_{3} \mathrm{BH}_{3}$ complex was obtained by a two-step synthesis. The first step involves formation of $\mathrm{Al}\left(\mathrm{BH}_{4}\right)_{3}$ by a metathesis reaction:

$$
\mathrm{AlCl}_{3}+3 \mathrm{LiBH}_{4} \rightarrow \mathrm{Al}\left(\mathrm{BH}_{4}\right)_{3}+3 \mathrm{LiCl}
$$

We used the same procedure described in our previous work, ${ }^{16}$ which is a modification of an earlier one. ${ }^{51}$ The final product is obtained by the following addition reaction:

$$
\mathrm{Al}\left(\mathrm{BH}_{4}\right)_{3}+\mathrm{NH}_{3} \mathrm{BH}_{3} \rightarrow \mathrm{Al}\left(\mathrm{BH}_{4}\right)_{3} \cdot \mathrm{NH}_{3} \mathrm{BH}_{3}
$$

For that purpose, $1 \mathrm{~mL}$ of freshly obtained liquid $\mathrm{Al}\left(\mathrm{BH}_{4}\right)_{3}$ is injected via syringe into a bottle with $70 \mathrm{mg}$ of $\mathrm{NH}_{3} \mathrm{BH}_{3}$ powder. The bottle is kept sealed for $72 \mathrm{~h}$ until large white crystals form (Figure S1 of the Supporting Information). The excess of liquid $\mathrm{Al}\left(\mathrm{BH}_{4}\right)_{3}$ was pumped off during $30 \mathrm{~s}$. The obtained crystals self-ignite when they come into contact with moisture and air.
X-ray Single-Crystal Analysis. The complex reveals two polymorphs. The crystals of $\alpha-\mathrm{Al}\left(\mathrm{BH}_{4}\right)_{3} \cdot \mathrm{NH}_{3} \mathrm{BH}_{3}$ were selected in the argon-filled glovebox and then measured at $100 \mathrm{~K}$ under a nitrogen flow (Oxford Cryosystems). For better completeness, two crystals were measured independently using a PILATUS $2 \mathrm{M}$ pixel detector and $\lambda=0.82103 \AA$ synchrotron X-ray radiation at the SNBL beamline, ESRF (Grenoble, France). The recorded data were indexed in monoclinic space group $P 2_{1} / c$ with $a=7.8585(2) \AA, b=6.8647$ (1) $\AA$, $c=15.7136(8) \AA$, and $\beta=96.429(4)^{\circ}$ and integrated by CrysAlisPro; ${ }^{52}$ the implemented absorption correction was applied. The data from the two crystals were integrated separately and scaled (not merged) in XPREP (Bruker) prior to structure solution and refinement.

Data for $\beta-\mathrm{Al}\left(\mathrm{BH}_{4}\right)_{3} \cdot \mathrm{NH}_{3} \mathrm{BH}_{3}$ were collected on a MAR345 image plate detector (Mo K $\alpha$ radiation, $\mathrm{Zr}$ filter). The crystals of $\beta-\mathrm{Al}\left(\mathrm{BH}_{4}\right)_{3}$. $\mathrm{NH}_{3} \mathrm{BH}_{3}$ were loaded into inert grease in an argon-filled glovebox and then measured at $295 \mathrm{~K}$ under a nitrogen flow (Oxford Cryosystems). The recorded data were indexed in a monoclinic cell and integrated with CrysAlisPro, and the absorption correction was applied. ${ }^{52}$ The structure was determined in space group $C c$ with $a=10.8196(8) \AA, b$ $=7.2809(4) \AA, c=11.3260(9) \AA$, and $\beta=107.69(1)$, with a pseudoinversion symmetry for $83 \%$ of the structure, as determined by ADDSYM in Platon.

All single-crystal structures were solved by direct methods and refined by a full matrix least-squares method on $F^{2}$ using SHELXL2014. ${ }^{53}$

X-ray Powder Diffraction. For variable-temperature in situ powder X-ray diffraction, the crystals of $\alpha$ - and $\beta$ - $\mathrm{Al}\left(\mathrm{BH}_{4}\right)_{3} \cdot \mathrm{NH}_{3} \mathrm{BH}_{3}$ were ground in an agate mortar inside the argon-filled glovebox and the powders were introduced into $0.7 \mathrm{~mm}$ glass capillaries that were sealed with vacuum grease. The capillaries were steadily heated from 20 to $100{ }^{\circ} \mathrm{C}$ with a nitrogen blower (Oxford Cryosystems) with heating rates of 1 and $0.2{ }^{\circ} \mathrm{C} / \mathrm{min}$. The two-dimensional data images obtained at SNBL were azimuthally integrated with Fit2D using $\mathrm{LaB}_{6}$ as a calibrant. ${ }^{54}$ The Rietveld method was used for the phase analysis and refinement with Fullprof Suite. ${ }^{55}$

NMR Spectroscopy. NMR spectra were acquired in toluene- $d_{8}$ on a Bruker Avance DRX500 spectrometer operating at 500.1 for ${ }^{1} \mathrm{H}$ $\left(160.5 \mathrm{MHz}\right.$ for ${ }^{11} \mathrm{~B}$ and $130.3 \mathrm{MHz}$ for $\left.{ }^{27} \mathrm{Al}\right)$. Chemical shifts are reported with reference to $\mathrm{SiMe}_{4}$ (TMS) for ${ }^{1} \mathrm{H}, \mathrm{BF}_{3} \cdot \mathrm{OEt}_{2}$ for ${ }^{11} \mathrm{~B}$, and 1.1 $\mathrm{M} \mathrm{Al}\left(\mathrm{NO}_{3}\right)_{3}$ in $\mathrm{D}_{2} \mathrm{O}$ for ${ }^{27} \mathrm{Al}$. Spectra were measured on solutions of $\alpha-\mathrm{Al}\left(\mathrm{BH}_{4}\right)_{3} \cdot \mathrm{NH}_{3} \mathrm{BH}_{3}$ crystals, as well as on the starting products $\mathrm{Al}\left(\mathrm{BH}_{4}\right)_{3}$ and $\mathrm{NH}_{3} \mathrm{BH}_{3}$ dissolved in toluene- $d_{8}$ for reference. After dissolving the crystals of $\alpha-\mathrm{Al}\left(\mathrm{BH}_{4}\right)_{3} \cdot \mathrm{NH}_{3} \mathrm{BH}_{3}$, we measured the evolution of spectra with time: fresh, after $2 \mathrm{~h}$, and after $18 \mathrm{~h}$. Other samples studied by NMR were aged at room temperature for 2 months and heated under argon up to $70{ }^{\circ} \mathrm{C}$ and up to $100-110{ }^{\circ} \mathrm{C}$ in sealed glass bottles using a mineral oil bath for 40 and $60 \mathrm{~min}$, respectively. The residues were dissolved in toluene- $d_{8}$ and measured at room temperature.

The deconvolution processing for ${ }^{27} \mathrm{Al}$ NMR spectra included one level of zero filling, exponential multiplication of the free induction decay with a line broadening (lb) factor of $1 \mathrm{~Hz}$, Fourier transform, and zero-order phase correction; no correction of the initial decay, no first-order phase correction, and no baseline correction were applied. The region between $8700 \mathrm{~Hz}(66.76 \mathrm{ppm})$ and $7700 \mathrm{~Hz}(59.09$ ppm) was submitted to deconvolution analyses using a homemade program developed in Excel. The ${ }^{27} \mathrm{Al}$ NMR signal was described as a first-order multiplet, constraining intensity ratios according to Pascal's triangle and imposing a Lorenztian line shape and identical line width for all of the components. A second-order polynomial (three adjustable parameters) accounted for the local baseline.

NMR data of the compounds recognized in the presented spectra. $\mathrm{B}_{2} \mathrm{H}_{6}:{ }^{1} \mathrm{H}$ NMR $\delta 3.89\left(\mathrm{q},{ }^{1} J_{\mathrm{B}, \mathrm{H}}=132 \mathrm{~Hz}\right.$, external hydrogens), -0.8 $\left({ }^{1} J_{\mathrm{B}, \mathrm{H}}=44 \mathrm{~Hz}\right.$, bridging hydrogens); ${ }^{11} \mathrm{~B}$ NMR $\delta 17.6-17.8\left(\mathrm{tt},{ }^{1} J_{\mathrm{B}, \mathrm{H}}=\right.$ $132 \mathrm{~Hz}) ;{ }^{11} \mathrm{~B}\left\{{ }^{1} \mathrm{H}\right\}$ NMR $\delta 17.6(\mathrm{~s})$. Presumably $\mathrm{Al}\left(\mathrm{BH}_{4}\right)_{3} \cdot \mathrm{NH}_{3} \mathrm{BH}_{3}$ : ${ }^{11} \mathrm{~B}$ NMR $\delta-21.8$ (quadruplet, ${ }^{1} J_{\mathrm{B}, \mathrm{H}}=92 \mathrm{~Hz}, \mathrm{BH}_{3}$ ), -33.8 (quint, $\left.{ }^{1} J_{\mathrm{B}, \mathrm{H}}=88 \mathrm{~Hz}, \mathrm{BH}_{4}^{-}\right) ;{ }^{11} \mathrm{~B}\left\{{ }^{1} \mathrm{H}\right\}$ NMR $\delta-21.9\left(\mathrm{~s}, \mathrm{BH}_{3}\right),-34.1(\mathrm{~s}$, $\left.\mathrm{BH}_{4}{ }^{-}\right) ;{ }^{27} \mathrm{Al}$ NMR $\delta 60.3$ (s, broad); ${ }^{27} \mathrm{Al}\left\{{ }^{1} \mathrm{H}\right\}$ NMR $\delta 60.3(\mathrm{~s})$. Decomposition product, presumably $\mathrm{Al}\left(\mathrm{BH}_{4}\right)_{3} \cdot \mathrm{NHBH}$ or its oligomer: 
${ }^{11} \mathrm{~B}$ NMR $\delta-34.4$ (quint, ${ }^{1} J_{\mathrm{B}, \mathrm{H}}=86 \mathrm{~Hz}, \mathrm{BH}_{4}{ }^{-}$); ${ }^{11} \mathrm{~B}\left\{{ }^{1} \mathrm{H}\right\}$ NMR $\delta$ $-34.4\left(\mathrm{~s}, \mathrm{BH}_{4}{ }^{-}\right) ;{ }^{27} \mathrm{Al}$ NMR $\delta 63.0$ [nonuplet (doublet of heptuplets), $J_{\text {doublet }}=89.4 \mathrm{~Hz}, J_{\text {heptuplet }}=46.4 \mathrm{~Hz}, \mathrm{BH}_{4}{ }^{-}$, and $\left.{ }^{1} J_{\mathrm{Al}, \mathrm{H}}\right] ;{ }^{27} \mathrm{Al}\left\{{ }^{1} \mathrm{H}\right\} \mathrm{NMR}$ $\delta 63.0(\mathrm{~s})$.

Raman Spectroscopy. Raman spectra with $1064 \mathrm{~nm}$ excitation were recorded from 4000 to $100 \mathrm{~cm}^{-1}$ with a Bruker RFS 100/s FTRaman spectrometer $(I=200 \mathrm{~mW})$ at room temperature using a diode-pumped, air-cooled Nd:YAG laser for excitation. The powder sample was placed in a $0.7 \mathrm{~mm}$ glass capillary under argon and sealed with vacuum grease. Variable-temperature Raman spectroscopy was performed using the same spectrometer and temperature control chamber under an argon flow. The spectra were recorded in a stepwise manner every $5{ }^{\circ} \mathrm{C}$ from 30 to $125^{\circ} \mathrm{C}$.

TGA, DSC, and MS Analyses. TGA and DSC analyses were performed on powder samples after preliminary X-ray powder diffraction analysis. The data were collected with TGA/SDTA 851 Mettler and DSC 821 Mettler devices with heating rates of 1 and 5 ${ }^{\circ} \mathrm{C} / \mathrm{min}$ from 25 to $200{ }^{\circ} \mathrm{C}$. The samples for the TGA and DSC analyses were loaded in the argon-filled glovebox into crucibles with caps and sealed into aluminum pans, respectively. The experiments were conducted under a nitrogen flow of $10 \mathrm{~mL} / \mathrm{min}$ to prevent hydrolysis or oxidation.

Mass spectrometry (MS) analysis of the residual gas was performed using a Hiden Analytical HPR-20 QMS sampling system. The samples (each approximately $2 \mathrm{mg}$ ) were loaded into an $\mathrm{Al}_{2} \mathrm{O}_{3}$ crucible and heated from room temperature to $70{ }^{\circ} \mathrm{C}$, fixing this temperature for 2 $\mathrm{h}\left(1{ }^{\circ} \mathrm{C} / \mathrm{min}\right.$ for both $)$ in an argon flow of $20 \mathrm{~mL} / \mathrm{min}$. The decomposition up to $200{ }^{\circ} \mathrm{C}$ was measured by a ThermoStar GSD $301 \mathrm{~T}$ spectrometer coupled with a simultaneous TGA/DTA 851 Mettler device. The released gases were analyzed for hydrogen, ammonia, diborane, and borazine in both experiments.

Volumetric Study. Volumetric analysis was performed using a Hiden Isochema IMI-SHP analyzer. Four decomposition experiments with the $\mathrm{Al}\left(\mathrm{BH}_{4}\right)_{3} \cdot \mathrm{NH}_{3} \mathrm{BH}_{3}$ complex were conducted with $50-60 \mathrm{mg}$ of sample, under a 5 bar back-pressure of hydrogen/helium, from 30 to $70{ }^{\circ} \mathrm{C}$ and from 30 to $100{ }^{\circ} \mathrm{C}$ at a heating rate of $1{ }^{\circ} \mathrm{C} / \mathrm{min}$. The gas release was calculated from the calibrated volumes of the system, excluding the volume of the glass wool $\left(2.06 \mathrm{~g} / \mathrm{cm}^{3}\right)$. Rehydrogenation of the samples decomposed at 70 and $100{ }^{\circ} \mathrm{C}$ was conducted at $\sim 150$ bar of hydrogen, by heating them to 70 and $100{ }^{\circ} \mathrm{C}$ and cooling them to $30^{\circ} \mathrm{C}$ at a rate of $0.1{ }^{\circ} \mathrm{C} / \mathrm{min}$.

\section{RESULTS AND DISCUSSION}

$\mathrm{Al}\left(\mathrm{BH}_{4}\right)_{3} \cdot \mathrm{NH}_{3} \mathrm{BH}_{3}$ can be obtained from commercially available chemicals, $\mathrm{AlCl}_{3}, \mathrm{LiBH}_{4}$, and $\mathrm{NH}_{3} \mathrm{BH}_{3}$, in two steps. The synthesis requires an inert atmosphere as the intermediate $\mathrm{Al}\left(\mathrm{BH}_{4}\right)_{3}$ is highly pyrophoric. ${ }^{16}$ The reaction of $\mathrm{Al}\left(\mathrm{BH}_{4}\right)_{3}$ with powder $\mathrm{NH}_{3} \mathrm{BH}_{3}$ at room temperature gives white crystals (see Figure S1 of the Supporting Information). The reaction was allowed to proceed on average for 3 days. Ball milling is expected to dramatically accelerate the reaction on a large scale; however, one should avoid extended vacuum pumping of the excess $\mathrm{Al}\left(\mathrm{BH}_{4}\right)_{3}$, as it decreases the yield of the product.

The detailed characterization of the complex is presented below. It aimed first to identify its different crystal forms coexisting under ambient conditions, second to improve our understanding of its complex dehydrogenation, and third to determine the nature of the Al-based intermediate species.

Crystal Structure of the Complex. We have characterized two polymorphs of $\mathrm{Al}\left(\mathrm{BH}_{4}\right)_{3} \cdot \mathrm{NH}_{3} \mathrm{BH}_{3}$ : the low-temperature $\alpha$ phase and the high-temperature $\beta$-phase. $\alpha$ - $\mathrm{Al}\left(\mathrm{BH}_{4}\right)_{3} \cdot \mathrm{NH}_{3} \mathrm{BH}_{3}$ is observed only in freshly synthesized samples, while it slowly transforms at room temperature into the $\beta$-phase. In both structures, aluminum atoms coordinate three $\mathrm{BH}_{4}^{-}$anions and one $\mathrm{NH}_{3} \mathrm{BH}_{3}$ molecule, forming a mononuclear $\mathrm{Al}\left(\mathrm{BH}_{4}\right)_{3}$. $\mathrm{NH}_{3} \mathrm{BH}_{3}$ heteroleptic complex, like the one shown in Figure 1 . Weak dihydrogen bonds between $\mathrm{BH}_{4}^{-}$and $-\mathrm{NH}_{3}$ groups

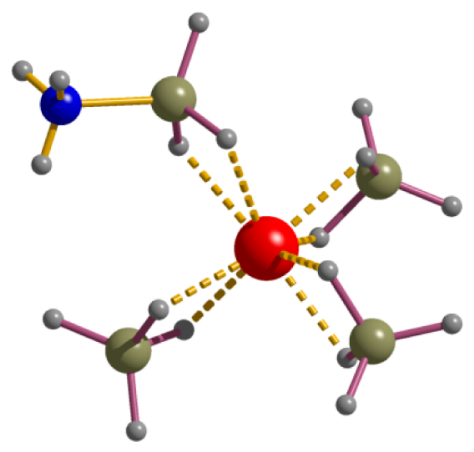

Figure 1. Isolated $\mathrm{Al}\left(\mathrm{BH}_{4}\right)_{3} \cdot \mathrm{NH}_{3} \mathrm{BH}_{3}$ complex, in which the $\mathrm{Al}^{3+}$ cation coordinates three $\mathrm{BH}_{4}{ }^{-}$anions and one $\mathrm{NH}_{3} \mathrm{BH}_{3}$ molecule.

associate the complexes into a three-dimensional structure. $\mathrm{N}-$ $\mathrm{H}^{\sigma+} \ldots \mathrm{H}^{\sigma-}-\mathrm{B}$ bonds are often bifurcated on the $\mathrm{N}-\mathrm{H}$ side; thus, the $\mathrm{H} \cdots \mathrm{H}$ distances are rather long, exceeding $2.6 \AA$, while $\mathrm{N}-$ $\mathrm{H}^{\sigma+} \ldots \mathrm{H}^{\sigma-}$ angles are not very close to $180^{\circ}$ (see Table S6 of the Supporting Information).

The $\mathrm{Al}^{3+}$ cation is linked via $\mathrm{BH}_{2}$ edges to three $\mathrm{BH}_{4}^{-}$anions and to one ammonia borane molecule. With respect to $\mathrm{B}$ atoms, $\mathrm{Al}$ adopts a distorted tetrahedral coordination, and the $\mathrm{AlH}_{8}$ polyhedron has the shape of a snub disphenoid, like that of $\mathrm{Mg}$ in $\mathrm{Mg}\left(\mathrm{BH}_{4}\right)_{2}$ structures. $^{56,57}$ This contrasts with planar trigonal $\mathrm{AlB}_{3} /$ trigonal prismatic $\mathrm{AlH}_{6}$ coordination in both known polymorphs of $\mathrm{Al}\left(\mathrm{BH}_{4}\right)_{3}{ }^{58,59}$ The $\mathrm{Al}-\mathrm{B}$ distances with $\mathrm{BH}_{4}{ }^{-}$ions are in the narrow range of $2.21-2.23 \AA$ and are slightly longer than $2.10-2.15 \AA$ as determined by gas electron diffraction and in the solid $\alpha, \beta-\mathrm{Al}\left(\mathrm{BH}_{4}\right)_{3} \cdot{ }^{58,59}$ It is nearly identical to the $2.22-2.26 \AA \mathrm{Al}-\mathrm{B}$ distances in $\mathrm{K}\left[\mathrm{Al}\left(\mathrm{BH}_{4}\right)_{4}\right]$ and $\left[\mathrm{Ph}_{3} \mathrm{MeP}\right]\left[\mathrm{Al}\left(\mathrm{BH}_{4}\right)_{4}\right]$, where the $\mathrm{Al}^{3+}$ cation is also coordinated to eight hydrogen atoms. ${ }^{16,60}$ The interatomic $\mathrm{Al}-\mathrm{B}$ distances involving ammonia borane's $\mathrm{BH}_{3}$ group are slightly longer $(2.31 \AA)$ than the distances to the $\mathrm{BH}_{4}^{-}$anions. They are still much shorter than metal-boron distances in other borohydride $-\mathrm{NH}_{3} \mathrm{BH}_{3}$ complexes, namely, 2.63-2.92 in $\left(\mathrm{LiBH}_{4}\right)_{2} \cdot \mathrm{NH}_{3} \mathrm{BH}_{3}, \mathrm{LiBH}_{4} \cdot \mathrm{NH}_{3} \mathrm{BH}_{3}$, and $\mathrm{Ca}\left(\mathrm{BH}_{4}\right)_{2}$. $2 \mathrm{NH}_{3} \mathrm{BH}_{3}{ }^{46,47}$ The $\mathrm{Al}-\mathrm{H}$ bond distances vary accordingly: they range from $1.65(8)-1.81(1) \AA$ where $\mathrm{BH}_{4}^{-}$is involved, similar to those in Al-based complex hydrides, ${ }^{22,60}$ to $1.86(1)-$ 1.96(8) $\AA$ where the $\mathrm{BH}_{3}$ group is involved. The latter are much shorter than the 2.44 and $2.50 \AA \mathrm{Al}-\mathrm{H}$ bond distances in $\mathrm{Ca}\left(\mathrm{BH}_{4}\right)_{2} \cdot\left(\mathrm{NH}_{3} \mathrm{BH}_{3}\right)_{2}$ and the 2.08-2.32 $\AA$ distances in $\left(\mathrm{LiBH}_{4}\right)_{2} \cdot \mathrm{NH}_{3} \mathrm{BH}_{3}$.

Relative Stability of the Polymorphs. The phase analysis by X-ray powder diffraction was performed prior to further characterization of the complex by other techniques. Both $\alpha$ and $\beta-\mathrm{Al}\left(\mathrm{BH}_{4}\right)_{3} \cdot \mathrm{NH}_{3} \mathrm{BH}_{3}$ can be obtained as single phases using the synthesis procedures described above (Figure 2). Figure S2 of the Supporting Information shows Rietveld refinement profiles for single-phase samples of the $\alpha$ - and $\beta$ polymorphs. $\alpha-\mathrm{Al}\left(\mathrm{BH}_{4}\right)_{3} \cdot \mathrm{NH}_{3} \mathrm{BH}_{3}$ was found as a single phase only in freshly prepared samples. Within a few days at room temperature, we find a mixture of the two phases. The crystals of the $\beta$-phase cooled to $100 \mathrm{~K}$ did not turn into the $\alpha$-phase; thus, the $\alpha$ to $\beta$ transition is irreversible or at least slow.

Variable-temperature in situ powder X-ray diffraction of both polymorphs at a heating rate of $1{ }^{\circ} \mathrm{C} / \mathrm{min}$ (Figure 3) reveals that $\alpha-\mathrm{Al}\left(\mathrm{BH}_{4}\right)_{3} \cdot \mathrm{NH}_{3} \mathrm{BH}_{3}$ undergoes a first-order phase transition to $\beta-\mathrm{Al}\left(\mathrm{BH}_{4}\right)_{3} \cdot \mathrm{NH}_{3} \mathrm{BH}_{3}$ at $\sim 62{ }^{\circ} \mathrm{C}$; the latter is melting and presumably decomposing at $\sim 71{ }^{\circ} \mathrm{C}$. The heating of the single-phase sample of the $\beta$-phase with a 5 -fold lower 


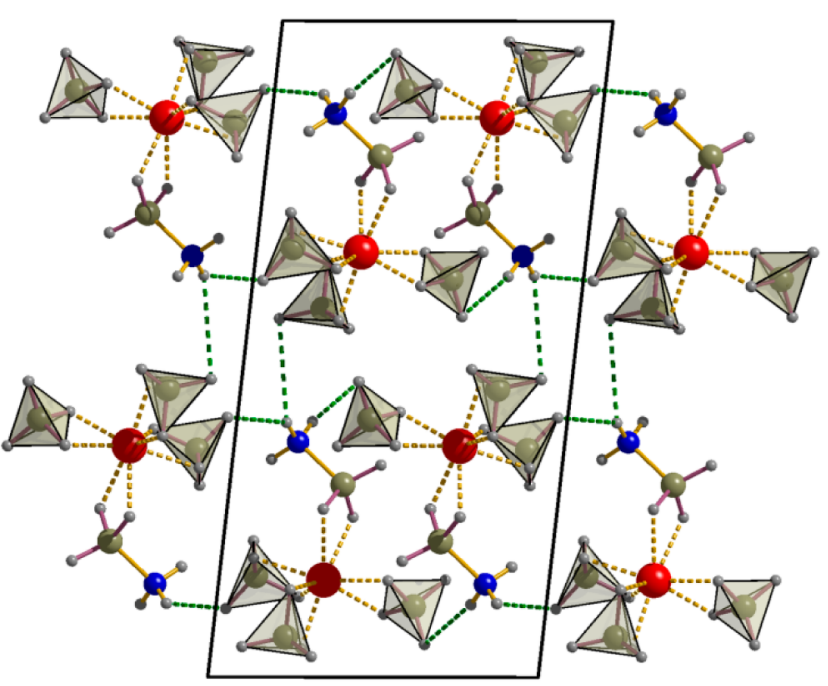

a)

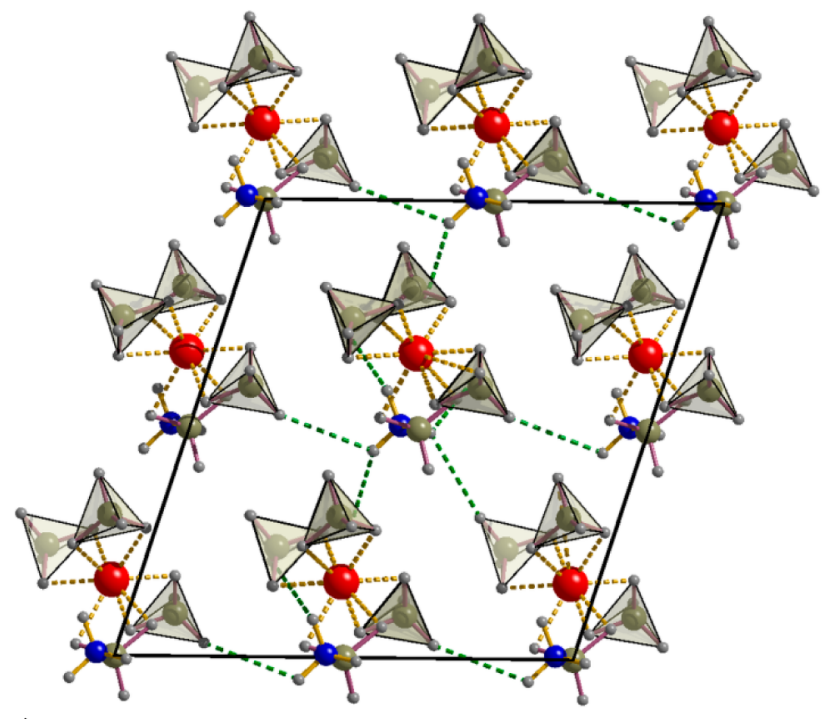

b)

Figure 2. Association of molecular $\mathrm{Al}\left(\mathrm{BH}_{4}\right)_{3} \cdot \mathrm{NH}_{3} \mathrm{BH}_{3}$ complexes by dihydrogen bonds in (a) the $\alpha$-phase and (b) the $\beta$-phase.

rate of $0.2^{\circ} \mathrm{C} / \mathrm{min}$ reveals melting at the lower temperature of $52{ }^{\circ} \mathrm{C}$ (see Figure S3 of the Supporting Information), thus confirming the simultaneous decomposition.

Raman Spectroscopy. The Raman spectrum of $\beta$ $\mathrm{Al}\left(\mathrm{BH}_{4}\right)_{3} \cdot \mathrm{NH}_{3} \mathrm{BH}_{3}$ is shown in Figure 4. Several stretching $\mathrm{B}-\mathrm{H}$ modes can are recognized in the $2080-2600 \mathrm{~cm}^{-1}$ range, similar to the vibrational modes of $\left[\mathrm{Al}\left(\mathrm{BH}_{4}\right)_{4}\right]^{-}$and $\mathrm{Al}\left(\mathrm{BH}_{4}\right)_{3}$, where $\mathrm{BH}_{4}^{-}$is coordinated to $\mathrm{Al}^{3+}$ in a bidentate manner. ${ }^{22,61}$ Three intense peaks at 2441, 2496, and $2530 \mathrm{~cm}^{-1}$ probably belong to the outward $\mathrm{B}-\mathrm{H}$ (terminal) stretching modes from different $\mathrm{BH}_{4}$ and $\mathrm{BH}_{3}$ groups; the peaks from 2040 to 2300 $\mathrm{cm}^{-1}$ correspond to inward $\mathrm{B}-\mathrm{H}$ (bridging with $\mathrm{Al}$ ) stretching modes. The vibrations between 950 and $1650 \mathrm{~cm}^{-1}$ can be attributed to $\mathrm{B}-\mathrm{H}$ bending, and the peaks near $490 \mathrm{~cm}^{-1}$ likely correspond to an $\mathrm{Al}-\mathrm{B}$ stretching band, as observed for $\left[\mathrm{Al}\left(\mathrm{BH}_{4}\right)_{4}\right]^{-}$anion and for $\mathrm{Al}\left(\mathrm{BH}_{4}\right)_{3} \cdot{ }^{2,61,62}$ The $\mathrm{N}-\mathrm{H}$ stretching region is represented by two intense peaks at 3240 and $3299 \mathrm{~cm}^{-1}$ that are slightly shifted to lower frequencies with respect to the symmetric $\left(3250 \mathrm{~cm}^{-1}\right)$ and antisymmetric $\left(3316 \mathrm{~cm}^{-1}\right)$ stretches in $\mathrm{NH}_{3} \mathrm{BH}_{3}{ }^{63}$ Literature reports the $\mathrm{B}-$

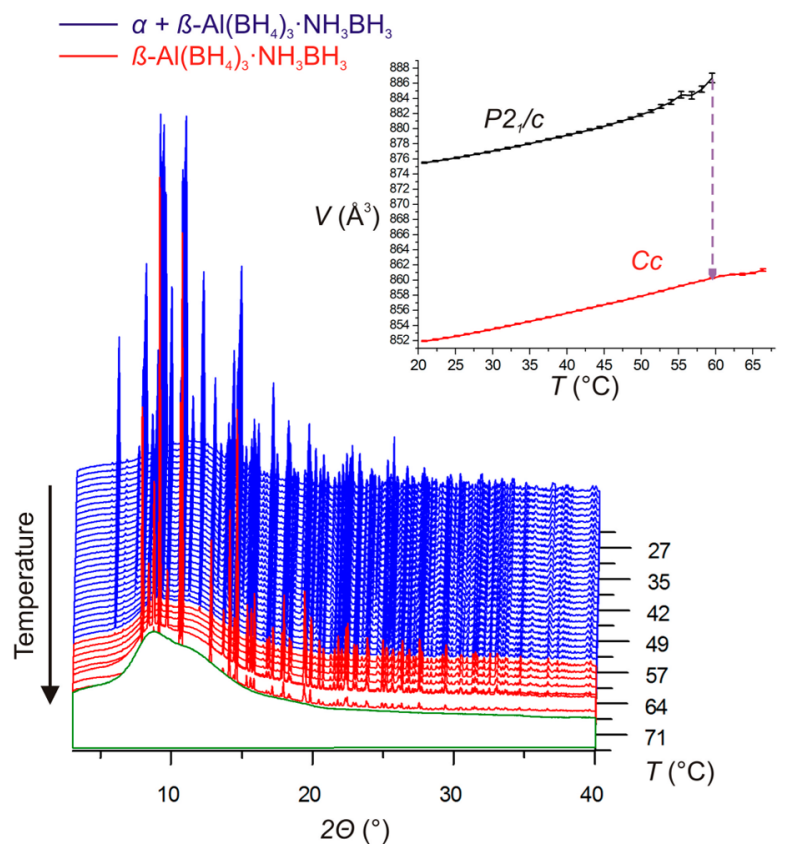

Figure 3. Variable-temperature in situ synchrotron powder X-ray diffraction of $\alpha$ - and $\beta$ - $\mathrm{Al}\left(\mathrm{BH}_{4}\right)_{3} \cdot \mathrm{NH}_{3} \mathrm{BH}_{3}(\lambda=0.821693 \AA$ from SNBL). The unit cell volume as a function of temperature is shown in the inset.

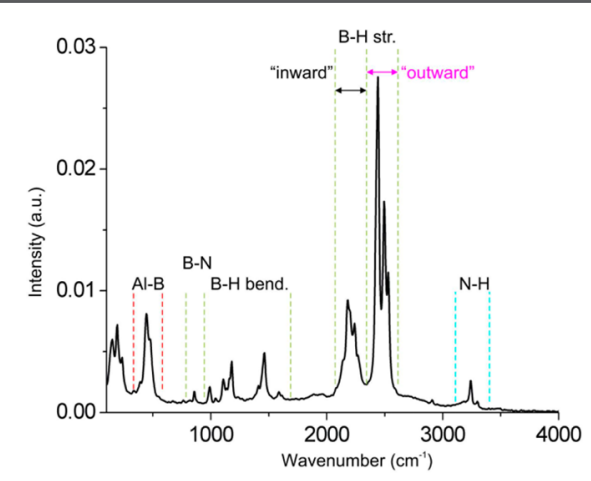

Figure 4. Raman spectrum of $\beta-\mathrm{Al}\left(\mathrm{BH}_{4}\right)_{3} \cdot \mathrm{NH}_{3} \mathrm{BH}_{3}$.

$\mathrm{N}$ vibrations around $800 \mathrm{~cm}^{-1}$, and we can surmise that the vibration at $858 \mathrm{~cm}^{-1}$ belongs to the $\mathrm{B}-\mathrm{N}$ stretch in the coordinated $\mathrm{NH}_{3} \mathrm{BH}_{3}{ }^{63}$

Thermal Analysis: Two Decomposition Steps. Several thermal effects are observed when the samples are heated from 25 to $200{ }^{\circ} \mathrm{C}$ (Figure 5a). The first endothermic $(\sim 39 \mathrm{~kJ} / \mathrm{mol})$ peak near $46-52{ }^{\circ} \mathrm{C}$ (DSC) corresponds to the melting/ decomposition of $\beta$ - $\mathrm{Al}\left(\mathrm{BH}_{4}\right)_{3} \cdot \mathrm{NH}_{3} \mathrm{BH}_{3}$. The next endothermic $(\sim 65 \mathrm{~kJ} / \mathrm{mol})$ peak near $93{ }^{\circ} \mathrm{C}$ is assigned to the second decomposition step. TGA also displays two decomposition steps: the first starts at $\sim 60{ }^{\circ} \mathrm{C}$ and finishes at $\sim 80{ }^{\circ} \mathrm{C}$, and the second is centered around $90^{\circ} \mathrm{C}$. The bottom part of Figure $5 \mathrm{~b}$ shows that the higher heating rate increases the decomposition temperature from $\sim 60{ }^{\circ} \mathrm{C}$ for $1{ }^{\circ} \mathrm{C} / \mathrm{min}$ to $\sim 77{ }^{\circ} \mathrm{C}$ for $5{ }^{\circ} \mathrm{C} /$ min. This behavior is similar to that of ammonia borane, which showed different decomposition reaction pathways depending on the heating rate. ${ }^{36,37}$

We performed additional experiments aiming to separate the two decomposition steps, holding samples at fixed temperatures of 70 and $80{ }^{\circ} \mathrm{C}$. Remarkably, the mass loss asymptotically reached very different values of 5 and $25 \mathrm{wt} \%$, respectively (see 


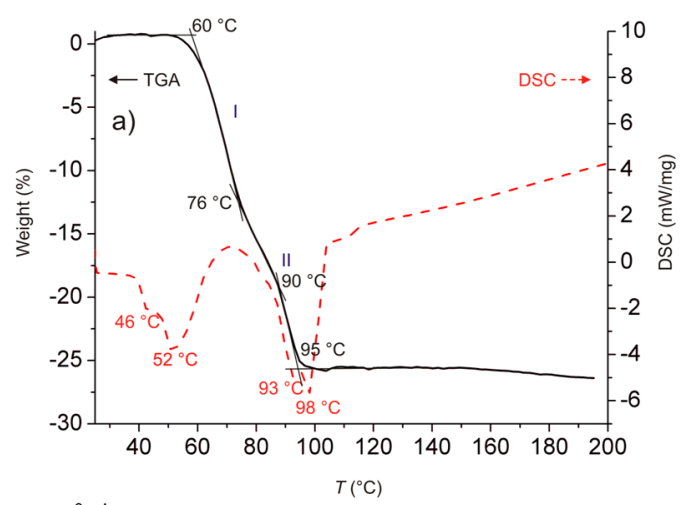

The MS determination of the released gases was made in the same manner as TGA: the first decomposition step is characterized isothermally at $70{ }^{\circ} \mathrm{C}$ and the complete decomposition at temperatures above $100{ }^{\circ} \mathrm{C}$. Remarkably, desorption at $70{ }^{\circ} \mathrm{C}$ showed exclusively the release of hydrogen, while the possible impurities of ammonia, diborane, and borazane were not detected (see Figure 5c). Further heating provokes release of diborane, which was detected around the start of the second decomposition step at $85^{\circ} \mathrm{C}$ (see Figure S4 of the Supporting Information). Variable-temperature in situ Raman spectroscopy also confirmed decomposition of the complex around $75{ }^{\circ} \mathrm{C}$ (see Figure S5 of the Supporting Information). Unfortunately, the detailed characterization of the decomposition products of the first and second steps was not possible from Raman spectra. Visually, the residue of the fully decomposed (at $150{ }^{\circ} \mathrm{C}$ ) samples resembles foamed polymer-like products.

Volumetric Study of the Decomposition and a Reversibility Test. Taking into account the information from TGA and DSC analysis, we performed two volumetric measurements at different temperatures: $70{ }^{\circ} \mathrm{C}$, which corresponds to the first decomposition step, and $100{ }^{\circ} \mathrm{C}$, which relates to the second decomposition step.

Samples were steadily heated at a rate of $1{ }^{\circ} \mathrm{C} / \mathrm{min}$, as in the TGA experiment. Decomposition at $70{ }^{\circ} \mathrm{C}$ produces $\sim 1.15$ $\mathrm{mmol}$ of gas from $0.54 \mathrm{mmol}$ of the starting complex (Figure 6), i.e., $2.15 \mathrm{~mol}$ of gas per formula unit (f.u.). To verify this

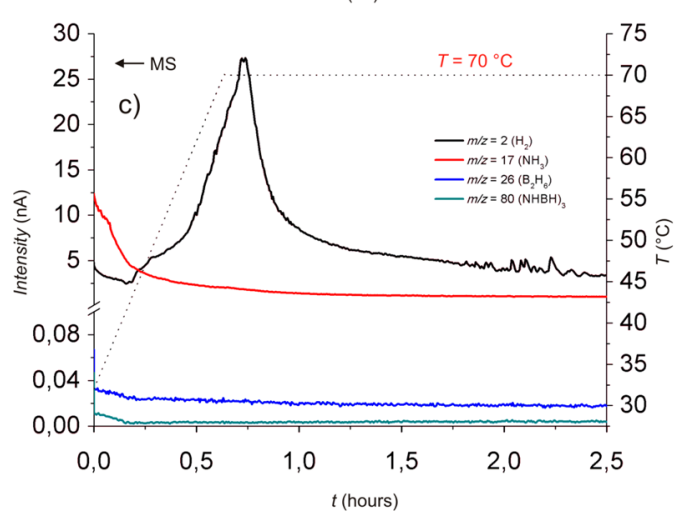

Figure 5. Thermal analysis of the $\mathrm{Al}\left(\mathrm{BH}_{4}\right)_{3} \cdot \mathrm{NH}_{3} \mathrm{BH}_{3}$ complex: (a) overlap of the TGA and DSC data collected at a rate of $1{ }^{\circ} \mathrm{C} / \mathrm{min}$ and (b) weight loss as a function of time, at constant temperatures of 70 and $80{ }^{\circ} \mathrm{C}$ (top graph), and as a function of heating rate (bottom). (c) MS curves of evolving gases measured in the temperature range of 30$70{ }^{\circ} \mathrm{C}$. The signals of ammonia, diborane, and borazane are close to zero level, which confirms the high purity of hydrogen release at 70 ${ }^{\circ} \mathrm{C}$.

Figure 5b). The decomposition step at $70{ }^{\circ} \mathrm{C}$ with a $\sim 5$ wt $\%$ loss looks very interesting, as it suggests that potentially pure hydrogen is released from the sample (see the Volumetric Study for more details). The decomposition of the other borohydride-ammonia borane complexes, $M$ $\left(\mathrm{BH}_{4}\right)_{n}\left(\mathrm{NH}_{3} \mathrm{BH}_{3}\right)_{m}\left(n=1, m=1\right.$ or 2 for $\mathrm{M}=\mathrm{Li}^{+} ; n=m=$ 2 for $\mathrm{M}=\mathrm{Ca}^{2+}$ or $\mathrm{Mg}^{2+}$ ), yields significant amounts of ammonia, diborane, and borazine besides hydrogen on the first decomposition step. ${ }^{46-49}$ While these compounds undergo complete decomposition involving both borohydride and ammonia borane moieties, the thermal analysis of the title complex suggests the release of hydrogen from ammonia borane in the first step, followed by a diborane release (theoretical $27 \mathrm{wt} \%$ loss) in the second step. The volumetric and mass spectrometry studies help to verify this hypothesis.

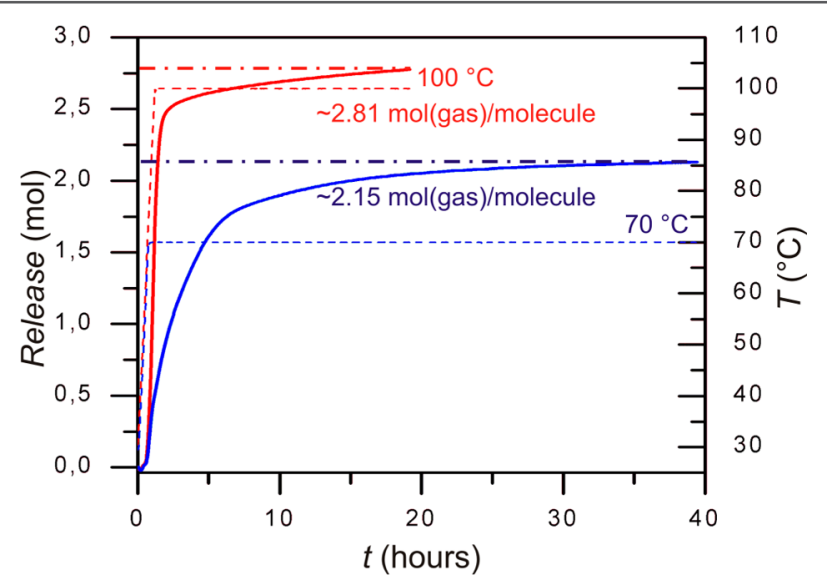

Figure 6. Volumetric analysis of $\mathrm{Al}\left(\mathrm{BH}_{4}\right)_{3} \cdot \mathrm{NH}_{3} \mathrm{BH}_{3}$ decomposition at $70{ }^{\circ} \mathrm{C}$ with $0.54 \mathrm{mmol}$ of the complex and at $100{ }^{\circ} \mathrm{C}$ with $0.58 \mathrm{mmol}$ of the complex, at a heating rate of $1{ }^{\circ} \mathrm{C} / \mathrm{min}$.

result, two additional volumetric experiments were conducted for the first step of the decomposition in $\mathrm{He}$ and $\mathrm{H}_{2}$ backpressure at $70{ }^{\circ} \mathrm{C}$, yielding 1.93 and $2.10 \mathrm{~mol}$ of gas per f.u. The second decomposition step at $100{ }^{\circ} \mathrm{C}$ shows the release of $\sim 2.81 \mathrm{mmol}$ of gas per f.u. Using the TGA data, we infer that the first decomposition step gives $\sim 2 \mathrm{~mol}$ of hydrogen per $\mathrm{Al}\left(\mathrm{BH}_{4}\right)_{3} \cdot \mathrm{NH}_{3} \mathrm{BH}_{3}$ unit $(\sim 5$ wt \% mass loss) and the second step gives almost $1 \mathrm{~mol}$ of diborane (close to $\sim 25 \mathrm{wt} \%$ mass loss).

Our attempts to rehydrogenate, at 150 bar, the samples decomposed at 70 and $100{ }^{\circ} \mathrm{C}$ were not successful: the $\mathrm{H}_{2}$ pressure returns exactly to the same value after the very slow cooling (see Figure S6 of the Supporting Information).

NMR Spectroscopy Study of $\mathrm{Al}\left(\mathrm{BH}_{4}\right)_{3} \cdot \mathrm{NH}_{3} \mathrm{BH}_{3}$ and Its Decomposition. ${ }^{1} \mathrm{H},{ }^{11} \mathrm{~B}$, and ${ }^{27} \mathrm{Al}$ NMR spectra were recorded on $\mathrm{Al}\left(\mathrm{BH}_{4}\right)_{3}$ prior to being used in the synthesis of 
$\mathrm{Al}\left(\mathrm{BH}_{4}\right)_{3} \cdot \mathrm{NH}_{3} \mathrm{BH}_{3}$ and were found to be in good agreement with the literature. ${ }^{64}$ The interpretation of the ${ }^{1} \mathrm{H}$ NMR spectra being difficult because of the presence of very broad signals around $0.5 \mathrm{ppm}$, we focused our attention on the interpretation of ${ }^{11} \mathrm{~B}$ and ${ }^{27} \mathrm{Al}$ NMR spectra. The main ${ }^{11} \mathrm{~B}$ peak for $\mathrm{Al}\left(\mathrm{BH}_{4}\right)_{3}$ is found at $-36.3 \mathrm{ppm}$ with a negligible amount of diborane, because of the slow $\mathrm{Al}\left(\mathrm{BH}_{4}\right)_{3}$ degradation, present at $17.8 \mathrm{ppm}$ (not even visible in Figure $7 \mathrm{~b}$ ). The main ${ }^{27} \mathrm{Al}$ peak for

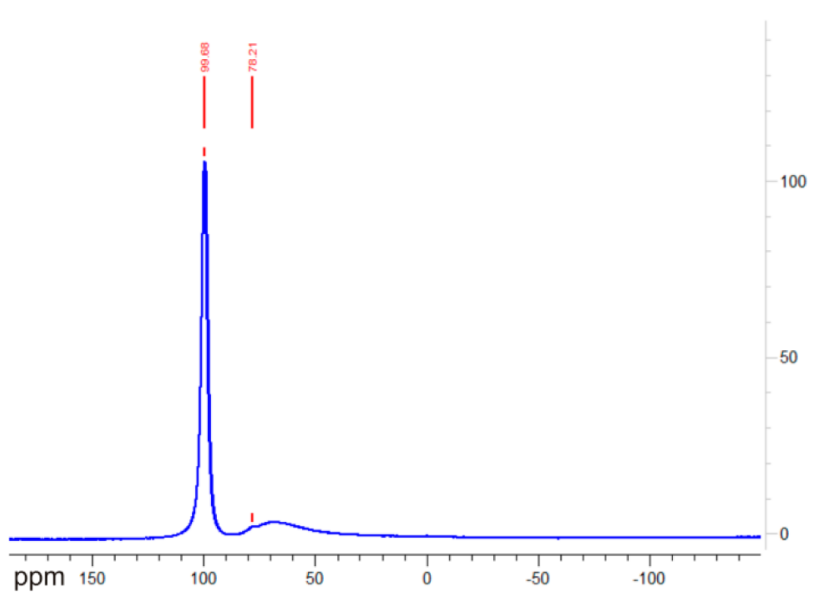

a)

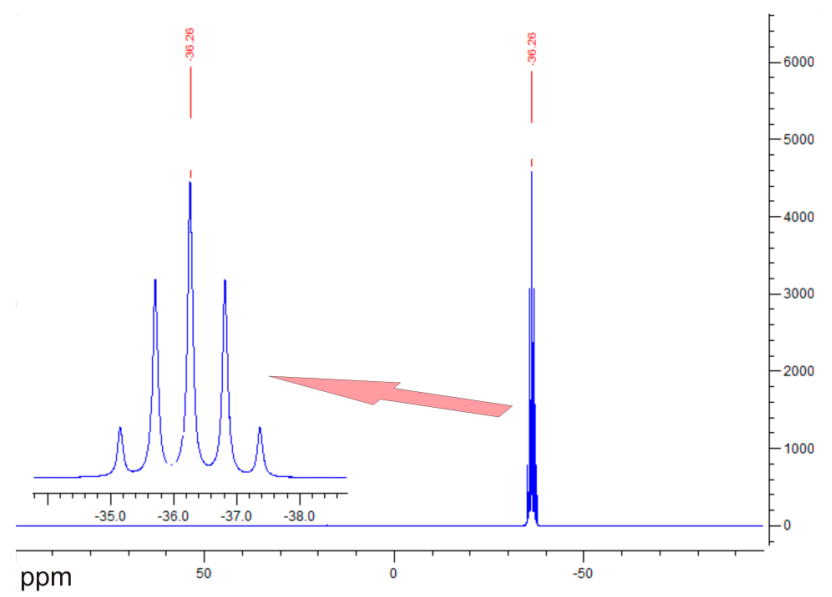

b)

Figure 7. (a) ${ }^{27} \mathrm{Al} \mathrm{NMR}$ and (b) ${ }^{11} \mathrm{~B}$ NMR spectra of $\mathrm{Al}\left(\mathrm{BH}_{4}\right)_{3}$ in toluene- $d_{8}$.

$\mathrm{Al}\left(\mathrm{BH}_{4}\right)_{3}$ is at $99.7 \mathrm{ppm}$, and an unknown impurity observed at $78.2 \mathrm{ppm}$ (Figure 7a,b). Broad signals in the spectra originate from the solid Al-containing material in the probe, and from the ${ }^{11} \mathrm{~B}$ in the borosilicate NMR tubes, as proven by blank measurements, and can be removed by using a backward linear prediction during data processing.

Samples of $\mathrm{Al}\left(\mathrm{BH}_{4}\right)_{3} \cdot \mathrm{NH}_{3} \mathrm{BH}_{3}$ stored in a glovebox at $25-30$ ${ }^{\circ} \mathrm{C}$ over 2 weeks turned into a viscous mass, prompting us to study by NMR spectroscopy the decomposition products obtained at different temperatures. To observe the changes in $\mathrm{Al}\left(\mathrm{BH}_{4}\right)_{3} \cdot \mathrm{NH}_{3} \mathrm{BH}_{3}$, we performed experiments on (1) a freshly dissolved sample in toluene- $d_{8},(2)$ the same sample in solution kept at room temperature for 2 and $18 \mathrm{~h}$, and (3) samples heated to 70 and $100{ }^{\circ} \mathrm{C}$, as in Volumetric Study, and then dissolved in toluene- $d_{8}$. Complete data are shown in Figures S8-S18 of the Supporting Information.

$\mathrm{Al}\left(\mathrm{BH}_{4}\right)_{3} \cdot \mathrm{NH}_{3} \mathrm{BH}_{3}$ does not decompose into $\mathrm{Al}\left(\mathrm{BH}_{4}\right)_{3}$, as no signal at $99.7 \mathrm{ppm}$ in the ${ }^{27} \mathrm{Al} \mathrm{NMR}$ spectrum appears; instead, we observe a signal at $60.3 \mathrm{ppm}$ that is not present after $18 \mathrm{~h}$. In the ${ }^{11} \mathrm{~B}$ NMR spectrum (Figure $10 \mathrm{~b}$ ), we observe a sextuplet, consisting of two overlapped quintets at -33.8 and $-34.4 \mathrm{ppm}$, and a quadruplet at $-21.9 \mathrm{ppm}$ (Figure $8 \mathrm{~b}$ and

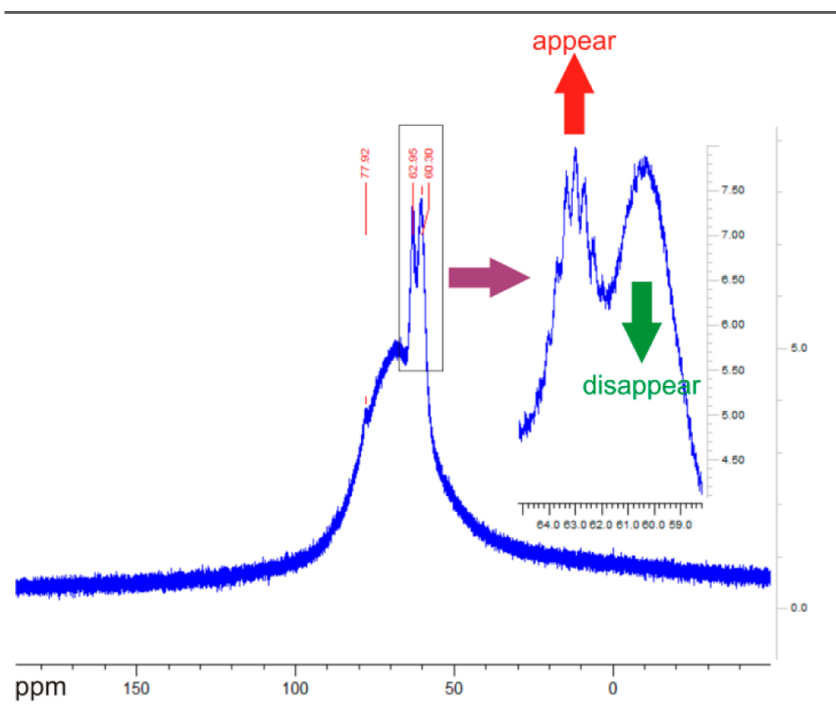

a)

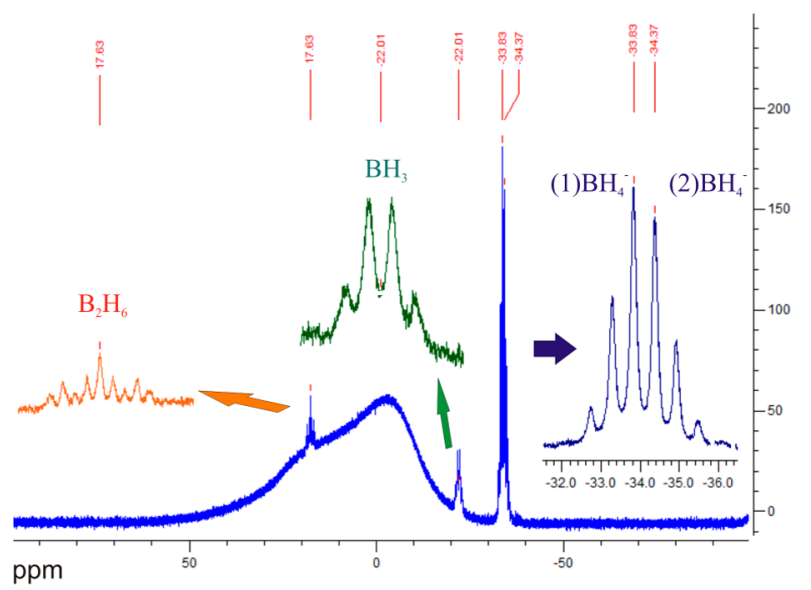

b)

Figure 8. (a) ${ }^{27} \mathrm{Al}$ NMR and (b) ${ }^{11} \mathrm{~B}$ NMR spectra of freshly dissolved $\mathrm{Al}\left(\mathrm{BH}_{4}\right)_{3} \cdot \mathrm{NH}_{3} \mathrm{BH}_{3}$ in toluene- $d_{8}$.

Figures S9-S12 of the Supporting Information). The presence of a small amount of diborane $\mathrm{B}_{2} \mathrm{H}_{6}$ was observed as a triplet of triplets at $17.5 \mathrm{ppm}$ in the ${ }^{11} \mathrm{~B}$ NMR spectrum. ${ }^{65}$ It is likely the result of partial decomposition of $\mathrm{Al}\left(\mathrm{BH}_{4}\right)_{3} \cdot \mathrm{NH}_{3} \mathrm{BH}_{3}$ into $\mathrm{B}_{2} \mathrm{H}_{6}$, as for instance via a reaction

$$
\mathrm{Al}\left(\mathrm{BH}_{4}\right)_{3} \cdot \mathrm{NH}_{3} \mathrm{BH}_{3} \rightarrow\left[\mathrm{Al}\left(\mathrm{BH}_{4}\right)_{2}\left(\mathrm{NH}_{2}\right)\right]_{n}+\mathrm{H}_{2}+\mathrm{B}_{2} \mathrm{H}_{6}
$$

There is no diborane forming up to $70{ }^{\circ} \mathrm{C}$ in the absence of the solvent (see the MS data in Figure 5). However, the intensity of the diborane peak increases with time in the toluene solution.

In contrast to the broad signal of the starting compound at $60.3 \mathrm{ppm}$ that disappears over time, the intensity of a nonuplet 
at $63.0 \mathrm{ppm}$ increases in the ${ }^{27} \mathrm{Al}$ NMR spectrum (Figures $8 \mathrm{a}$ and $9 \mathrm{a})$. In the ${ }^{11} \mathrm{~B}$ NMR spectrum, a quintet at $-34.4 \mathrm{ppm}$,

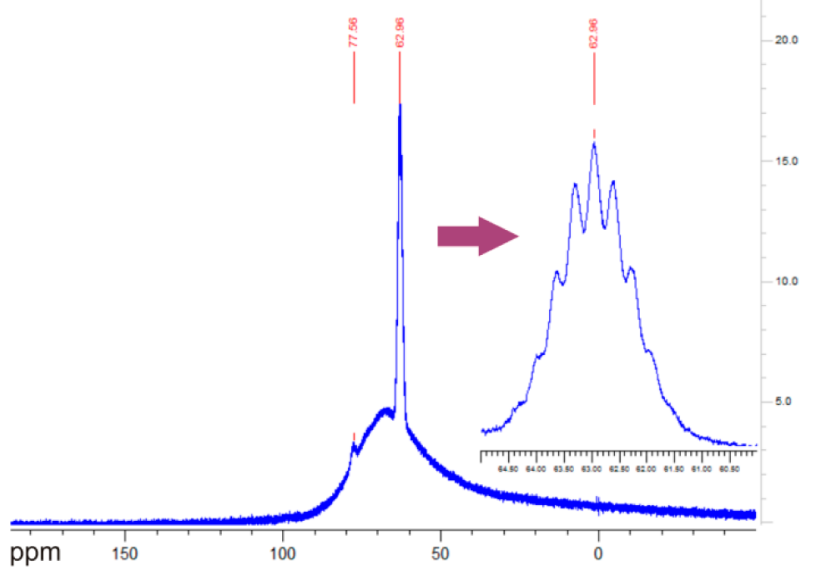

a)

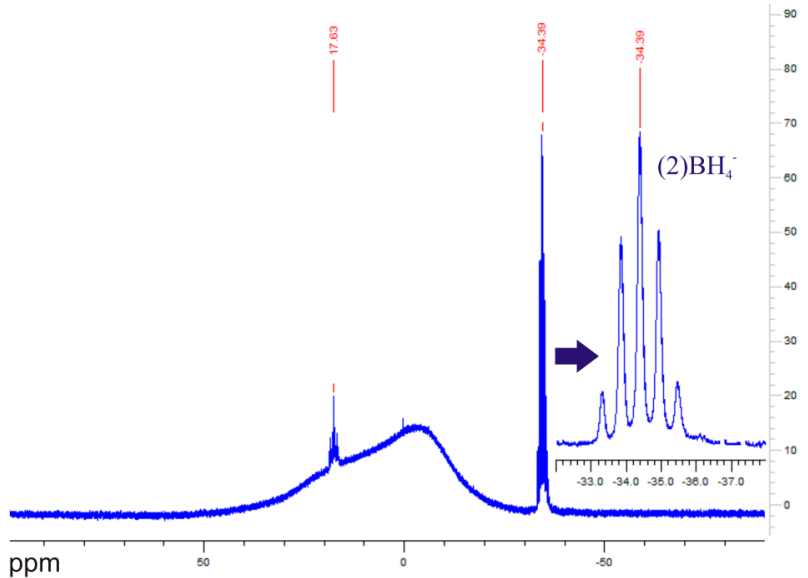

b)

Figure 9. (a) ${ }^{27} \mathrm{Al} \mathrm{NMR}$ and (b) ${ }^{11} \mathrm{~B}$ NMR spectra of $\mathrm{Al}\left(\mathrm{BH}_{4}\right)_{3}$. $\mathrm{NH}_{3} \mathrm{BH}_{3}$ dissolved in toluene- $d_{8}$ after $18 \mathrm{~h}$.

corresponding to $\mathrm{BH}_{4}^{-}$anion, increasingly dominates the spectrum over the disappearing signal at $-33.8 \mathrm{ppm}$ present at 2 and $18 \mathrm{~h}$ (Figures $8 \mathrm{~b}$ and $9 \mathrm{~b}$ ).

In the sample that decomposed at $\sim 70{ }^{\circ} \mathrm{C}$, the same main NMR signals, as in the $18 \mathrm{~h}$-aged sample spectrum, were observed at 63 and $-34.5 \mathrm{ppm}$ in the ${ }^{27} \mathrm{Al}$ and ${ }^{11} \mathrm{~B} \mathrm{NMR}$ spectra, respectively (compare Figures 9 and 10). The intensities of the several other minor signals at 82.0, 77.6, and $74.4 \mathrm{ppm}$ changed in the ${ }^{27} \mathrm{Al}$ spectrum. After $100{ }^{\circ} \mathrm{C}$, we observe (Figure S18 of the Supporting Information) only a single ${ }^{27} \mathrm{Al}$ NMR signal at $81.9 \mathrm{ppm}$, which probably has the same nature as that at $82.0 \mathrm{ppm}$ after heating to $70{ }^{\circ} \mathrm{C}$ (Figure 10a).

${ }^{11} \mathrm{~B}$ NMR signals at $-35.0 \mathrm{ppm}$ are present in all the samples as well as an unknown signal in the ${ }^{27} \mathrm{Al}$ spectrum and are suspected to belong to $\mathrm{AlB}_{x} \mathrm{H}_{y}$ products, as well as the ${ }^{11} \mathrm{~B}$ signals at $-36.0 \mathrm{ppm}$ with ${ }^{27} \mathrm{Al}$ at 81.9 and $82.0 \mathrm{ppm}$. They can be the result of reaction of $\mathrm{B}_{2} \mathrm{H}_{6}$ with starting compound or/ and forming products previously described for $\mathrm{Al}\left(\mathrm{BH}_{4}\right)_{3}$ with $\mathrm{B}_{2} \mathrm{H}_{6}$, giving the $\mathrm{AlB}_{4} \mathrm{H}_{11}$ at $100{ }^{\circ} \mathrm{C}$. ${ }^{65}$ The assignment of the remaining weak ${ }^{11} \mathrm{~B}$ signals is not certain, but they likely belong

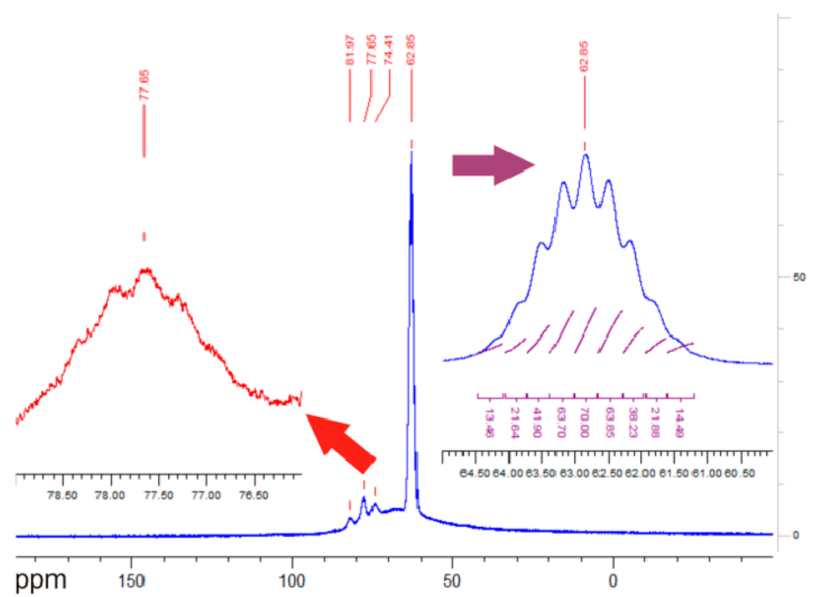

a)

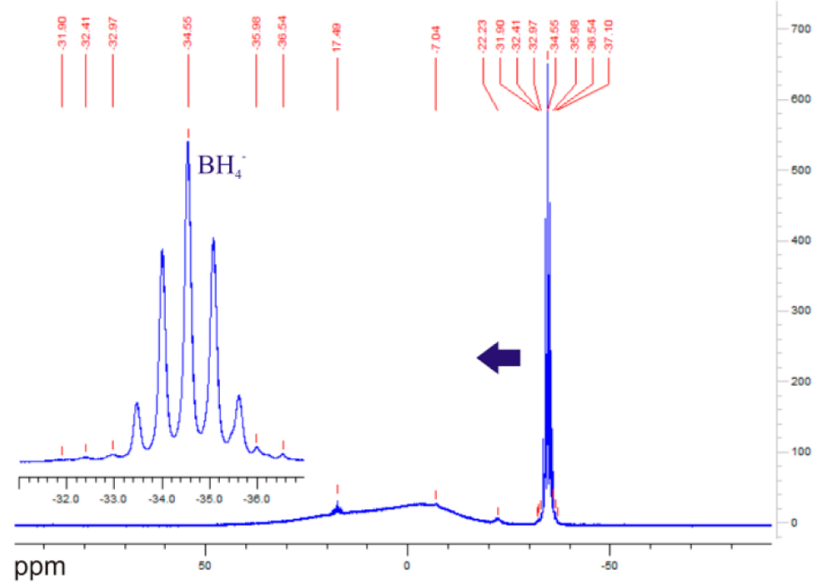

b)

Figure 10. (a) ${ }^{27} \mathrm{Al} \mathrm{NMR}$ and (b) ${ }^{11} \mathrm{~B}$ NMR spectra of $\mathrm{Al}\left(\mathrm{BH}_{4}\right)_{3}$. $\mathrm{NH}_{3} \mathrm{BH}_{3}$ heated to $\sim 70{ }^{\circ} \mathrm{C}$ and dissolved in toluene- $d_{8}$.

to polyhydroboranes. The presence of compounds such as DADB $\left[\mathrm{BH}_{2}\left(\mathrm{NH}_{3}\right)_{2}\right] \mathrm{BH}_{4}$ is excluded because no characteristic $\mathrm{BH}_{2}$ signal at approximately $-15 \mathrm{ppm}$ on the ${ }^{11} \mathrm{~B}$ spectrum was detected in our experiment. ${ }^{66}$

Notably, the fresh $\mathrm{Al}\left(\mathrm{BH}_{4}\right)_{3} \cdot \mathrm{NH}_{3} \mathrm{BH}_{3}$ sample kept in a toluene- $d_{8}$ solution at room temperature, the sample aged in the inert atmosphere at ambient temperature and then dissolved in toluene- $d_{8}$ (Figure S19 of the Supporting Information), and the sample heated to $70{ }^{\circ} \mathrm{C}$ and then dissolved in toluene- $d_{8}$ all give the same spectral features. No insoluble products were formed upon their dissolution in toluene. Therefore, it is likely the same decomposition pathway is followed in toluene solutions and in the absence of any solvent. This means we can interpret by NMR the decomposition intermediate obtained in TGA/DSC and volumetric experiments, responsible for the release of $2 \mathrm{~mol}$ of $\mathrm{H}_{2}$. Its fingerprint is the nonuplet at $63.0 \mathrm{ppm}$ in the ${ }^{27} \mathrm{Al}$ NMR spectrum, with an intensity distribution of 14:22:40:64:70:64:40:22:14. With proton decoupling, this nonuplet at $63.0 \mathrm{ppm}$ becomes a singlet (Figures S12a,b and $S 15 a, b)$, implying the splitting of this peak into nine lines is indeed caused by protons coupled to aluminum. The experimental signal exhibits nine maxima or shoulders, but as 
one can see in Figure 11a, it is not properly described by a firstorder nonuplet (relative intensity ratios of

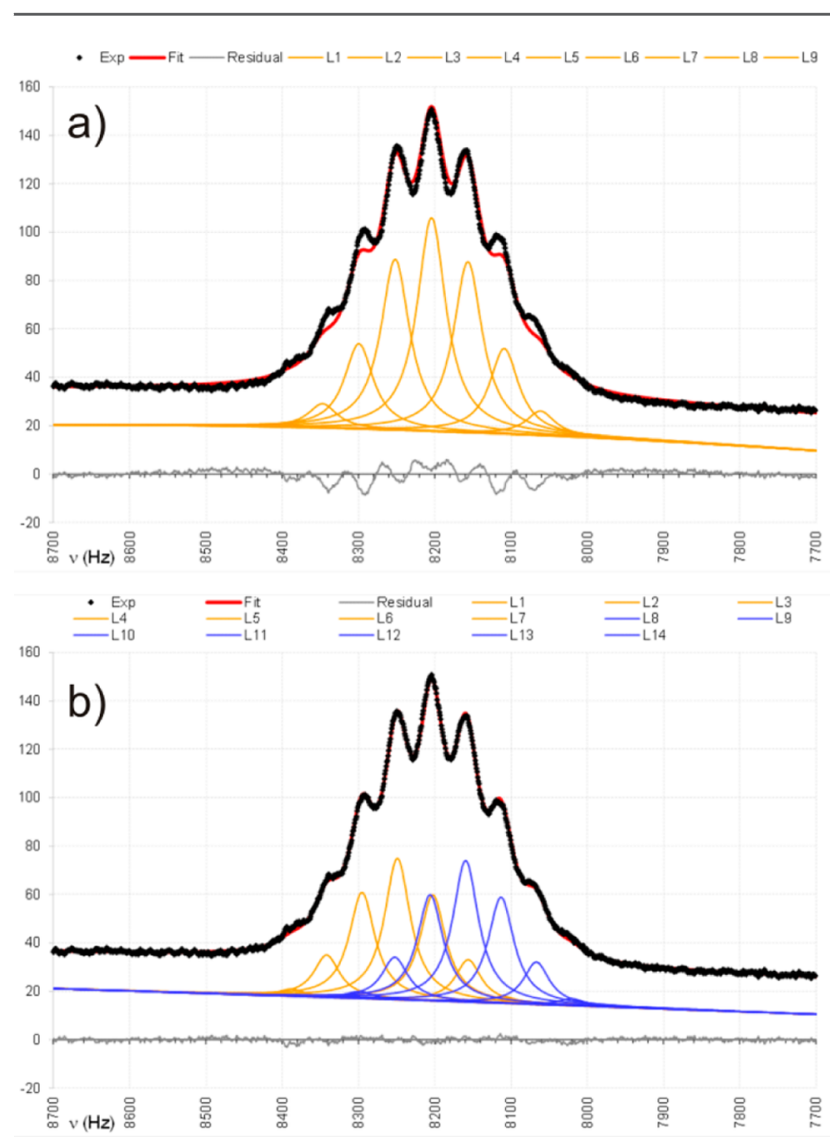

Figure 11. Best fit of (a) a first-order nonuplet and (b) a first-order doublet of heptuplets to the ${ }^{27} \mathrm{Al} \mathrm{NMR}$ signal observed at $63.0 \mathrm{ppm}$.

1:8:28:56:70:56:28:8:1; four adjustable parameters being chemical shift, line width, overall intensity, and one scalar coupling constant). In contrast, considering a doublet of heptuplets as a model yields excellent agreement (Figure 11b; relative intensity ratios of $\{1: 6: 15: 20: 15: 6: 1\}$ : $\{1: 6: 15: 20: 15: 6: 1\}$; five adjustable parameters, including the overall intensity). The relevant best-fit parameters are as follows: $\delta=62.954 \mathrm{ppm}, \Delta \nu_{1 / 2}=40.0 \mathrm{~Hz}$ (full line width at half-height corrected for $\mathrm{lb}$ ), and scalar coupling constants $J_{\text {doublet }}=89.4 \mathrm{~Hz}, J_{\text {heptuplet }}=46.4 \mathrm{~Hz}$. Our observed $J$ value of $46.4 \mathrm{~Hz}$ is similar to that reported for ${ }^{1} J_{\mathrm{Al}, \mathrm{H}}$ of $44 \mathrm{~Hz}$ in $\mathrm{Al}\left(\mathrm{BH}_{4}\right)_{3}{ }^{67}$

Decomposition Intermediate. The NMR study shows that the first step of the decomposition of $\mathrm{Al}\left(\mathrm{BH}_{4}\right)_{3} \cdot \mathrm{NH}_{3} \mathrm{BH}_{3}$ yields the product in which an $\mathrm{Al}$ ion is bound to three borohydride anions with edges and further bound to one hydrogen, most likely a part of an "HN-HB" molecule or its oligomers, as shown here:

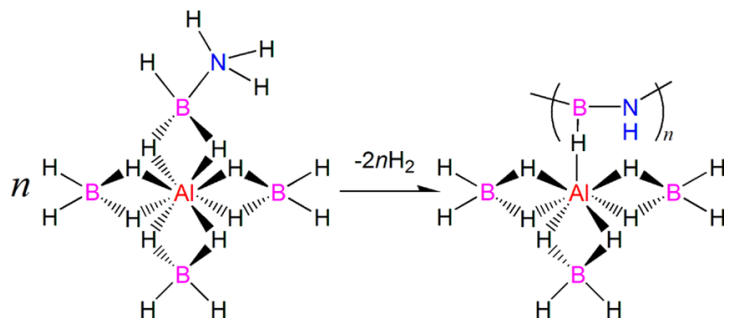

This evidence ties in very well with the results of our volumetric/TGA data suggesting the loss of two $\mathrm{H}_{2}$ molecules. The $6 \mathrm{H}+1 \mathrm{H}$ coordination of $\mathrm{Al}$ in the decomposition intermediate of $\mathrm{Al}\left(\mathrm{BH}_{4}\right)_{3} \cdot \mathrm{NH}_{3} \mathrm{BH}_{3}$ is the first evidenced by the deconvolution analysis of the ${ }^{27} \mathrm{Al}$ NMR spectrum. The molecular structure of the other aluminum borohydride complexes had been previously assigned on the basis of the supposed reaction equilibria in solutions and the known solidstate structures. ${ }^{60,68}$ In all cases, the $\mathrm{BH}_{4}$ anions are coordinated via the $\mathrm{BH}_{2}$ edges. Broad singlets at $49.5 \mathrm{ppm}$ in the spectra of $\left[\mathrm{Ph}_{3} \mathrm{MeP}\right]\left[\mathrm{Al}\left(\mathrm{BH}_{4}\right)_{4}\right]$ and $\left[\left(\mathrm{Ph}_{3} \mathrm{P}\right)_{2} \mathrm{~N}\right]\left[\mathrm{Al}\left(\mathrm{BH}_{4}\right)_{4}\right]$ in $\mathrm{CD}_{2} \mathrm{Cl}_{2}$ correspond to 8 equiv of $\mathrm{H}$ around $\mathrm{Al}^{60},{ }^{6}$ and that at $99.7 \mathrm{ppm}$ in the spectrum of $\mathrm{Al}\left(\mathrm{BH}_{4}\right)_{3}$ corresponds to 6 equiv of $\mathrm{H}$ around $\mathrm{Al}$; both are significantly different from the $63.0 \mathrm{ppm}$ shift we observed. The complex with the closest chemical shift is $\left[\mathrm{AlH}\left(\mathrm{BH}_{4}\right)_{2}\right]_{n}$ with a signal at $64.7 \mathrm{ppm}$ : it contains $4 \mathrm{H}$ from the $\mathrm{BH}_{4}$ groups and $2 \mathrm{H}$ bridging $\mathrm{Al}$ atoms. ${ }^{64}$

\section{CONCLUSIONS}

The thermal decomposition of the new complex, $\mathrm{Al}\left(\mathrm{BH}_{4}\right)_{3}$. $\mathrm{NH}_{3} \mathrm{BH}_{3}$, showed several striking features as compared with those of the previously investigated systems involving ammonia borane. We found that the decomposition of the complex in toluene solutions and upon heating the solid gives the same intermediate, releasing 2 equiv of hydrogen at $70^{\circ} \mathrm{C}$. It occurs at a temperature considerably lower than that for the pure $\mathrm{NH}_{3} \mathrm{BH}_{3}$, desorbing the first equivalent at $120{ }^{\circ} \mathrm{C}$ and the second at $150{ }^{\circ} \mathrm{C} .{ }^{69}$ To the best of our knowledge, this is the first metal borohydride-ammonia borane complex, resulting in hydrogen release. The other systems produce significant amounts of ammonia, diborane, and borazine on the first decomposition step. ${ }^{46-49}$ Also, we do not observe polyaminoboranes $(\mathrm{PAB})$ and polyborazylene, which form during liquidstate pyrolysis of $\mathrm{NH}_{3} \mathrm{BH}_{3}$ in ionic liquids and in the presence of strong Lewis and Brønsted acids. They would result in ${ }^{11} \mathrm{~B}$ signals in the range of -10 to $-13 \mathrm{ppm}$ for $\mathrm{BH}_{2}{ }^{+}$, near $-5 \mathrm{ppm}$ for $\mathrm{N}-\mathrm{BH}_{2}-\mathrm{N}$, and near $-22 \mathrm{ppm}$ from $\mathrm{BH}_{3}$ polymer terminating groups for $\mathrm{PAB}$ and $26 \mathrm{ppm}$ for polyborazylene. $^{70,71}$

The favorable decomposition pathway and the decomposition temperature make this system an attractive model for efficient elimination of hydrogen from ammonia borane. Taking into account all our data, we conclude that the decomposition of the staring complex into the Al-based intermediate can be assigned to $\mathrm{Al}\left(\mathrm{BH}_{4}\right)_{3}$ as a unique mild Lewis acid that coordinates both the starting and the dehydrogenated $\mathrm{BH}_{n}$ groups $(n=1$ or 3 ). This urges us to use other Al-based Lewis acids, less challenging with respect to stability and safety than aluminum borohydride.

This system is also encouraging in terms of a possible direct rehydrogenation of ammonia borane, which is currently regenerated successfully only via multistep chemical cycles. ${ }^{72}$ The striking property of the title system is the endothermic dehydrogenation on the first decomposition step $(39 \mathrm{~kJ} / \mathrm{mol}$, including melting), compared to the exothermic one for ammonia borane $(-22 \mathrm{~kJ} / \mathrm{mol}$ on the first decomposition step, including melting). ${ }^{36}$ Despite our first attempts to directly rehydrogenate the intermediate that were not successful, a catalyzed reaction may be possible. 


\section{ASSOCIATED CONTENT}

\section{S Supporting Information}

Supplementary XRD data with Rietveld refinements, NMR spectroscopy and volumetric data, and CIF files. This material is available free of charge via the Internet at http://pubs.acs.org.

\section{AUTHOR INFORMATION}

\section{Corresponding Author}

*Fax: +32 104727 07. E-mail: yaroslav.filinchuk@uclouvain. be.

\section{Notes}

The authors declare no competing financial interest.

\section{ACKNOWLEDGMENTS}

This work was supported by the Académie Universitaire Louvain (AUL), Belgium, under Grant ADi/DB/1058.2011 and FNRS (CC 1.5169.12, PDR T.0169.13, EQP U.N038.13). We thank ESRF for the beam time allocation at the SNBL and D. Chenyshov and V. Dyadkin for support. We thank Prof. Michel Luhmer (ULB) for the deconvolution analysis of the

${ }^{27} \mathrm{Al}$ NMR spectrum and Lars H. Jepsen and Prof. Torben R. Jensen (Aarhus University, Aarhus, Denmark) for help with MS analysis.

\section{REFERENCES}

(1) Orimo, S.; Nakamori, Y.; Eliseo, J. R; Züttel, A.; Jensen, C. M. Chem. Rev. 2007, 107, 4111-4132.

(2) Ley, M. B.; Jepsen, L. H.; Lee, Y.-S.; Cho, Y. W.; Colbe, J. B.; Dornheim, M.; Rokhi, M.; Jensen, J. O.; Sloth, M.; Filinchuk, Y.; Jørgensen, J. E.; Besenbacher, F.; Jensen, T. R. Mater. Today 2014, 17, $122-128$.

(3) Chua, Y. S.; Chen, P.; Wu, G.; Xiong, Z. Chem. Commun. 2011, 47, 5116-5129.

(4) Jepsen, L. H.; Ley, M. B.; Lee, Y.-S.; Cho, Y. W.; Dornheim, M.; Jensen, J. O.; Filinchuk, Y.; Jørgensen, J. E.; Besenbacher, F.; Jensen, T. R. Mater. Today 2014, 17, 129-135.

(5) Klebanoff, L. E.; Keller, J. O. Int. J. Hydrogen Energy 2013, 38, $4533-4576$.

(6) Li, H.-W.; Yan, Y.; Oriomo, S.-I.; Züttel, A.; Jensen, C. M. Energies 2011, 4, 185-214.

(7) Mao, J.; Guo, Z.; Nevikovets, I. P.; Liu, H. K.; Dou, S. H. J. Phys. Chem. C 2012, 116, 1596-1604.

(8) Burg, A. B.; Schlesinger, H. I. J. Am. Chem. Soc. 1940, 62, 34253429.

(9) Chłopek, K.; Frommen, C.; Lèon, A.; Zabara, O.; Fichtner, M. J. Mater. Chem. 2007, 17, 3496-3503.

(10) Kim, Y.; Hwang, S.-J.; Shim, J.-H.; Lee, Y.-S.; Han, H. N.; Cho, Y. W. J. Phys. Chem. C 2012, 116, 4330-4334.

(11) Schlesinger, H. I.; Sanderson, R. T.; Burg, A. B. J. Am. Chem. Soc. 1940, 62, 3421-3425.

(12) Volkov, V. V.; Myakishev, K. G. Izv. Sib. Otd. Akad. Nauk SSSR, Ser. Khim. Nauk 1977, 1, 77-82.

(13) Grochala, W.; Edwards, P. P. Chem. Rev. 2004, 104, 1283-1315.

(14) Nakamori, Y.; Miwa, K.; Ninomiya, A.; Li, H.; Ohba, N.; Towata, S.; Züttel, A.; Orimo, S. Phys. Rev. B 2006, 74, 45126.

(15) Rude, L. H.; Nielsen, T. K.; Ravnsbæk, D. B.; Bösenberg, U. M.; Ley, B.; Richter, B.; Arnbjerg, L. M.; Dornheim, M.; Filinchuk, Y.; Besenbacher, F.; Jensen, T. R. Phys. Status Solidi A 2011, 208, 17541773

(16) Lindemann, I.; Ferrer, R. D.; Dunsch, L.; Filinchuk, Y.; Černý, R.; Hagemann, H.; D’Anna, V.; Daku, L. M. L.; Schultz, L.; Gutfleisch, O. Chem.-Eur. J. 2010, 16, 8707-8712.

(17) Lindemann, I.; Ferrer, R. D.; Dunsch, L.; Černý, R.; Hagemann, H.; D’Anna, V.; Filinchuk, Y.; Schultz, L.; Gutfleisch, O. Faraday Discuss. 2011, 151, 231-242.
(18) Dovgaliuk, I.; Ban, V.; Sadikin, Y.; Černý, R.; Aranda, L.; Casati, N.; Devillers, M.; Filinchuk, Y. J. Phys. Chem. C 2014, 118, 145-153. (19) Ravnsbæk, D. B.; Filinchuk, Y.; Cerenius, Y.; Jakobsen, H. J.; Besenbacher, F.; Skibsted, J.; Jensen, T. R. Angew. Chem., Int. Ed. 2009, $48,6659-6663$

(20) Černý, R.; Ravnsbæk, D. B.; Schounwink, P.; Filinchuk, Y.; Penin, N.; Teyssier, J.; Smrčok, L.; Jensen, T. R. J. Phys. Chem. C 2012, $116,1563-1571$.

(21) Ravnsbæk, D. B.; Sørensen, L. H.; Filinchuk, Y.; Besenbacher, F.; Jensen, T. R. Angew. Chem., Int. Ed. 2012, 51, 3582-3586.

(22) Guo, Y. H.; Xia, G.; Zhu, Y.; Gao, L.; Yu, X. Chem. Commun. 2010, 46, 2599-2506.

(23) Guo, Y. H.; Sun, W. W.; Guo, Z. P.; Liu, H. K.; Sun, D. L.; Yu, X. B. J. Phys. Chem. C 2010, 114, 12823-12827.

(24) Soloveichik, G.; Her, J.-H.; Stephens, P. W.; Gao, Y.; Rijssenbeek, J.; Andrus, M.; Zhao, J.-C. Inorg. Chem. 2008, 47, 4290-4298.

(25) Chu, H.; Wu, G.; Xiong, Z.; Guo, J.; He, T.; Chen, P. Chem. Mater. 2010, 22, 6021-6028.

(26) Gu, Q.; Gao, L.; Guo, Y.; Tan, Y.; Wallwork, K. S.; Zhang, F.; Yu, X. Energy Environ. Sci. 2012, 5, 7590-7600.

(27) Yuan, F.; Gu, Q.; Chen, X.; Tan, Y.; Guo, Y.; Yu, X. J. Mater. Chem. 2012, 24, 3370-3379.

(28) Guo, Y. H.; Yu, X.; Sun, W.; Sun, D.; Yang, W. Angew. Chem., Int. Ed. 2011, 50, 1087-1091.

(29) Guo, Y. H.; Jiang, Y.; Xia, G.; Yu, X. Chem. Commun. 2012, 48, $4408-4410$.

(30) Sun, W.; Chen, X.; Gu, Q.; Wallwork, K. S.; Tan, Y.; Tang, Z.; Yu, X. Chem.-Eur. J. 2012, 18, 6825-6834.

(31) Yang, Y.; Liu, Y.; Wu, H.; Zhou, W.; Gao, M.; Pan, H. Phys. Chem. Chem. Phys. 2014, 16, 135-143.

(32) Guo, Y.; Wu, H.; Zhou, W.; Yu, X. J. Am. Chem. Soc. 2011, 133, 4690-4693.

(33) Johnson, S. R.; David, W. I. F.; Royse, D. M.; Sommariva, M.; Tang, C. Y. F.; Fabbiani, P. A.; Jones, M. O.; Edwards, P. P. Chem.Asian J. 2009, 4, 849-854.

(34) Zheng, X.; Wu, G.; Li, W.; Xiong, Z.; He, T.; Guo, J.; Chen, H.; Chen, P. Energy Environ. Sci. 2011, 4, 3593-3600.

(35) Chen, X.; Yu, X. J. Phys. Chem. C 2012, 116, 11900-11906.

(36) Wolf, G.; Baumann, J.; Baitalow, F.; Hoffmann, F. P. Thermochim. Acta 2000, 343, 19-25.

(37) Baitalow, F.; Baumann, J.; Wolf, G.; Jaenicke-Rößler, K.; Leiter, G. Thermochim. Acta 2002, 391, 159-168.

(38) Xiong, Z.; Yong, C. K.; Wu, G.; Chen, P.; Shaw, W.; Karkamkar, A.; Autrey, T.; Jones, M. O.; Johnson, S. I.; Edwards, P. P.; David, W. I. F. Nat. Mater. 2008, 7, 138-141.

(39) Diyabalanage, H. V. K.; Shrestha, R. P.; Semelsberger, T. A.; Scott, B. L.; Bowden, M. E.; Davis, B. L.; Burelli, A. K. Angew. Chem., Int. Ed. 2007, 46, 8995-8997.

(40) Wu, H.; Zhou, W.; Yildirim, T. J. Am. Chem. Soc. 2008, 130, 14834-14839.

(41) Luo, J.; Kang, X.; Wang, P. Energy Environ. Sci. 2013, 6, 10181025.

(42) Fijalkowski, K. J.; Genova, R. V.; Filinchuk, Y.; Budzianowski, A.; Derzci, M.; Jaroń, T.; Leszczynski, P. J.; Grohala, W. Dalton Trans. 2011, 40, 4407-4413.

(43) Wu, H.; Zhou, W.; Pinkerton, F. E.; Meyer, M. S.; Yao, Q.; Gadipelli, S.; Yildrim, T.; Rush, J. J. Chem. Commun. 2011, 47, 41024204.

(44) Luo, J.; Wu, H.; Zhou, W.; Kang, X.; Fang, Z.; Wang, P. Int. J. Hydrogen Energy 2013, 38, 197-204.

(45) Wu, C.; Wu, G.; Xiong, Z.; Han, X.; Chu, H.; He, T.; Chen, P. Chem. Mater. 2010, 22, 3-5.

(46) Luo, J.; Wu, H.; Zhou, W.; Kang, X.; Fang, Z.; Wang, P. Int. J. Hydrogen Energy 2012, 37, 10750-10757.

(47) Wu, H.; Zhou, W.; Pinkerton, F. E.; Meyer, M. S.; Srinivas, G.; Yildirim, T.; Udovic, T. J.; Rush, J. J. J. Mater. Chem. 2010, 20, 65506556. 
(48) Chen, X.; Yuan, F.; Gu, Q.; Yu, X. Dalton Trans. 2013, 42, $14365-14368$.

(49) Jepsen, L. H.; Ban, V.; Møller, K. T.; Lee, Y.-S.; Cho, Y. W.; Besenbacher, F.; Filinchuk, Y.; Skibsted, J.; Jensen, T. R. J. Phys. Chem. C 2014, 118, 12141-12153.

(50) Tan, Y.; Gu, Q.; Kimpton, J. A.; Li, Q.; Chen, X.; Ouyang, L.; Zhu, M.; Sun, D.; Yu, X. J. Mater. Chem. A 2013, 1, 10155-10165.

(51) Schlesinger, H. I.; Brown, H. C.; Hyde, E. K. J. Am. Chem. Soc. 1953, 75, 209-213.

(52) Xcalibur/SuperNova CCD system, CrysAlisPro Software system, version 1.171.36.24; Agilent Technologies UK Ltd.: Oxford, U.K., 2012.

(53) Sheldrick, G. M. Acta Crystallogr. 2008, A64, 112-122.

(54) Hammersley, A. P.; Svensson, S. O.; Hanfland, M.; Fitch, A. N.; Häusermann, D. High Pressure Res. 1996, 14, 2358.

(55) Rodriguez-Carvajal, J. Physica B 1993, 192, 55-69.

(56) Filinchuk, Y.; Černý, R.; Hagemann, H. Chem. Mater. 2009, 21, 925-933.

(57) Filinchuk, Y.; Richter, B.; Jensen, T. R.; Dmitriev, V.; Chernyshov, D.; Hagemann, H. Angew. Chem., Int. Ed. 2011, 50, $11162-11166$.

(58) Almenningen, A.; Gundersen, G.; Haaland, A. Acta Chem. Scand. 1968, 22, 328-334.

(59) Aldridge, S.; Blake, A. J.; Downs, A. J.; Gould, R. O.; Parsons, S.; Pulham, C. R. J. Chem. Soc., Dalton Trans. 1997, 1007-1012.

(60) Dou, D.; Liu, J.; Bauer, J. A. K.; Jordan, G. T., IV; Shore, S. G. Inorg. Chem. 1994, 33, 5443-5447.

(61) Coe, D. A.; Nibler, J. W. Spectrochim. Acta, Part A 1973, 29, 1789-1804.

(62) Jensen, J. O. Spectrochim. Acta, Part A 2003, 59, 1575-1578.

(63) Hess, N. J.; Bowden, M. E.; Parvanov, V. M.; Mundy, C.; Kathmann, S. M.; Schender, G. K.; Autrey, T. J. Chem. Phys. 2008, 128, 34508.

(64) Downs, A. J.; Jones, L. A. Polyhedron 1994, 13, 2401-2415.

(65) Chen, X.; Zhang, Y.; Wang, Y.; Zhou, W.; Knight, D. A.; Yisgedu, T. B.; Huang, Z.; Lingam, H. K.; Billet, B.; Udovic, T. J.; Brown, G. M.; Shore, S. G.; Wolverton, C.; Zhao, J.-C. Chem. Sci. 2012, 3, 3183-3191.

(66) Lingam, H. K.; Chen, X.; Zhao, J.-C.; Shore, S. G. Chem.-Eur. J. 2012, 18, 3490-3492.

(67) Maybury, P. C.; Ahnell, J. E. Inorg. Chem. 1967, 6, 1286-1291.

(68) Nöth, H.; Rurländer, R. Inorg. Chem. 1981, 20, 1062-1072.

(69) Karkamkar, A.; Aardahl, C.; Autrey, T. Mater. Matters (Milwaukee, WI, U.S.) 2007, 2, 6-9.

(70) (a) Bluhm, M. E.; Bradley, M. G.; Butterick, R., III; Kusari, U.; Sneddon, L. G. J. Am. Chem. Soc. 2006, 128, 7748-7749. (b) Himmelberger, D. W.; Alden, L. R.; Bluhm, M. E.; Sneddon, L. G. Inorg. Chem. 2009, 48, 9883-9889.

(71) Stephens, F. H.; Baker, R. T.; Matus, M. H.; Grant, D. J.; Dixon, D. A. Angew. Chem., Int. Ed. 2007, 46, 746-749.

(72) (a) Sutton, A. D.; Burrell, A. K.; Dixon, D. A.; Garner, E. B., III; Gordon, J. C.; Nakagawa, T.; Ott, K. C.; Robinson, J. P.; Vasiliu, M. Science 2011, 331, 1426-1429. (b) Summerscales, O. T.; Gordon, J. C. Dalton Trans. 2013, 42, 10075-10084. 